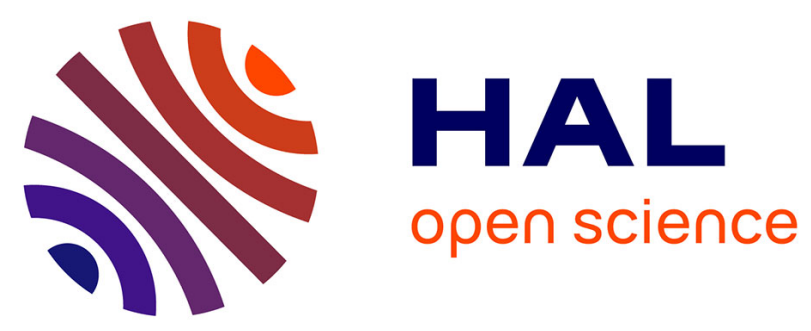

\title{
Calibration of silicone rubber rods as passive samplers for pesticides at two different flow velocities: Modeling of sampling rates under water boundary layer and polymer control
}

Alexis Martin, Christelle Margoum, Antoine Jolivet, Azziz Assoumani, Bachir El Moujahid, Jérôme Randon, Marina Coquery

\section{To cite this version:}

Alexis Martin, Christelle Margoum, Antoine Jolivet, Azziz Assoumani, Bachir El Moujahid, et al.. Calibration of silicone rubber rods as passive samplers for pesticides at two different flow velocities: Modeling of sampling rates under water boundary layer and polymer control. Environmental Toxicology and Chemistry, 2018, 37 (4), pp.1208-1218. 10.1002/etc.4050 . hal-01803608

\section{HAL Id: hal-01803608 https://hal.science/hal-01803608}

Submitted on 16 May 2020

HAL is a multi-disciplinary open access archive for the deposit and dissemination of scientific research documents, whether they are published or not. The documents may come from teaching and research institutions in France or abroad, or from public or private research centers.
L'archive ouverte pluridisciplinaire HAL, est destinée au dépôt et à la diffusion de documents scientifiques de niveau recherche, publiés ou non, émanant des établissements d'enseignement et de recherche français ou étrangers, des laboratoires publics ou privés. 
1 Correspondence: Dr Christelle Margoum, Irstea, UR MALY, 5 rue de la Doua, CS 20244, F-

2 69625, Villeurbanne Cedex, France

3 E-mail: christelle.margoum@irstea.fr

$4 \quad$ Tel: +33472208711

5

6 Running Head: Silicone rubber rods as passive samplers for pesticides 


\section{Calibration of silicone rubber rods as passive samplers for pesticides at two}

9 different flow velocities: modelling of sampling rates under water boundary

10 layer and polymer control

11 A. Martin $\dagger$, C. Margoum* $\uparrow$, A. Jolivet $\dagger$, A. Assoumani $\dagger$, B. El Moujahid $\dagger$, J. Randon $\ddagger$, M.

12 Coquery $\dagger$

$13 \dagger$ Irstea, UR MALY, 5 rue de la Doua, CS 20244, F-69625 Villeurbanne Cedex, France

14 † Univ Lyon, CNRS, Université Claude Bernard Lyon 1, ENS de Lyon, Institut des Sciences

15 Analytiques, UMR 5280, 5 rue de la Doua, F-69100 Villeurbanne, France

16 *Corresponding author: Tel: + 334722087 11; Fax: + 3347847 78 75; Email address: christelle.margoum@irstea.fr

17 


\section{Abstract}

There is a need to determine time-weighted average concentrations of polar contaminants such as pesticides by passive sampling in environmental waters. Calibration data for silicone rubber (SR)-based passive samplers are lacking for this class of compounds. The calibration data, sampling rate $\left(R_{s}\right)$ and partition coefficient between SR and water $\left(K_{s w}\right)$ were precisely determined for 23 pesticides and 13 candidate performance reference compounds (PRCs) in a laboratory calibration system over $14 \mathrm{~d}$ for two water flow velocities, $5 \mathrm{~cm} \mathrm{~s}^{-1}$ and $20 \mathrm{~cm} \mathrm{~s}^{-1}$. Results showed that an in situ exposure duration of $7 \mathrm{~d}$ left a SR rod passive sampler configuration in the linear or curvilinear uptake period for 19 of the pesticides studied. A change in the transport mechanism from polymer control to water boundary layer control was observed for pesticides with a $\log K_{s w}$ of around 3.3. The PRC candidates were not fully relevant to correct the impact of water flow velocity on $R_{s}$. We therefore propose an alternative method based on an overall resistance to mass transfer model to adjust $R_{s}$ from laboratory experiments to in situ hydrodynamic conditions. We estimated diffusion coefficients $\left(D_{s}\right)$ and thickness of water boundary layer $\left(\delta_{\mathrm{w}}\right)$ as adjustable model parameters. $\log D_{s}$ values ranged from -12.13 to $-10.07 \mathrm{~m}^{2} \mathrm{~s}^{-1}$. The estimated $\delta_{\mathrm{w}}$ value showed a power function correlation with water flow velocity.

Keywords: pesticides, polydimethylsiloxane, freshwaters, mass transfer model, monitoring 


\section{Introduction}

The monitoring of trace levels of pesticides with a wide range of physical and chemical properties is a challenge for sampling and analysis to evaluate water resource quality. The variability in the discharge of pesticides into the environment, such as during flood events in small agricultural watersheds, requires the development of suitable methods that take temporal variations into account [1]. Passive sampling offers a promising alternative to classical grab sampling. It allows the determination of representative time-weighted average concentrations of contaminants, such as pesticides in freshwaters, at lower logistical and analytical costs [2].

Passive sampling community experts recently recommended monophasic polymers (e.g. silicone rubber (SR) or low density polyethylene (LDPE) as passive sampler materials of choice for hydrophobic and non-ionised organic compounds [3]. These passive samplers are available in a large variety of shapes: sheets, tubes, rods or coated stir bars named "Passive SBSE" (Stir Bar Sorptive Extraction) [4]. Modelling of contaminant uptake mechanisms in monophasic polymers, such as SR, is now well-documented for passive sampling of hydrophobic contaminants (PAHs and PCBs) [5-11]. Although SRs are strongly hydrophobic [12], they can extract organic compounds with a broad range of polarities (log $\left.K_{o w}>1-2\right)$ from water but only a few studies have focused on pesticides [13-17]. Sorption properties of SRs for polar contaminants have mainly been assessed by determining partition coefficients between the SR and water at equilibrium $\left(K_{s w}\right)$, but if equilibrium is not attained, the determination of representative time-weighted average concentrations in water requires determining uptake kinetic parameters such as sampling rates $\left(R_{s}\right)$ or diffusion coefficients $\left(D_{s}\right)$ in the SR for every compound studied [18-20]. The uptake kinetic parameters are dependent on the variation of environmental factors including water flow velocity $[5,7,8]$, 
temperature, salinity [21] and biofouling [22, 23]. To correct for environmental variability, and especially water flow velocity, $R_{s}$ can be estimated from the dissipation rates of performance reference compounds (PRCs) with which the passive sampler is spiked beforehand [24]. A second method, described by Estoppey et al. [7] with SR sheets, is based on correction factors derived from a power function relationship between the compound uptake and water flow velocity. This new method was introduced to correct PCB concentrations among sites with great differences in water flow velocity, where PRC-based $R_{s}$ overcorrected the impact of varying flow velocities. Estoppey et al. [8] recently improved their method for PCBs by using a simple linear correlation between $R_{s}$ and flow velocity. For SRs, a close agreement between this second method and PRC correction was reported for flow velocities from $10 \mathrm{~cm} \mathrm{~s}^{-1}$ to $60 \mathrm{~cm} \mathrm{~s}^{-1}$ [8], and a similar linear correlation was observed by O'Brien et al. [25] using a passive flow monitor. This method has the advantages of being accessible by the operator applying passive samplers, less time consuming, less expensive than PRC-based methods and not influenced by uncertainties in $\log K_{s w}$ and $R_{S}$ determination $[8]$.

The determination of $R_{s}$ requires a calibration experiment with a constant concentration of contaminants and controlled experimental parameters (constant temperature and adjustable flow velocity) [26]. For SRs, few calibrations have been conducted for pesticides and especially for polar pesticides $[6,14,17,27]$. These calibration studies highlighted the need for an experimental design adapted to pesticide properties with short exposure monitoring ( $<15$ d). Emelogu et al. [27] quantified urea herbicide in field studies with SR-based passive samplers, but lacked calibration data to convert mass accumulated by the SR into water concentration.

The main goal of this study was to determine $R_{s}$ and $K_{s w}$ for 24 polar and non-polar pesticides $\left(0.6<\log K_{o w}<5.5\right)$ with an experimental calibration, in order to estimate an appropriate 
deployment period for linear uptake in freshwaters. We also assessed the impact of water flow velocity on the uptake of pesticides. The use of 13 deuterated pesticides as PRC candidates was evaluated to correct $R_{\mathrm{s}}$ for differences in flow velocity. The kinetic variables were determined using a home-made calibration system with adjustable water flow velocity and a diffusive source of pesticides. The theoretical model of overall resistance to mass transfer [28] was first applied to estimate $D_{s}$ values. In a second step, we then used this model to predict $R_{s}$ of pesticides for other water flow velocities in order to simplify the calculation of timeweighted average concentrations in different field applications.

\section{Mass transfer resistance model in silicone rubber-}

\section{based passive samplers}

The mass transfer of contaminants into a passive sampler depends mainly on both the characteristics of the device and the physical and chemical properties of the sampled analytes, but it depends also on environmental factors. We focused only on the theory for membranefree or monophasic samplers, such as SR plates. In this configuration, the exchange process is driven by different transport mechanisms involving transport of the compound by diffusion through the water, diffusion across the thickness of the receiving phase/ polymer. The transport across the biofilm layer for long exposure in water was neglected in the present work. Each transport mechanism contributes to the resistance to mass transfer $\left(1 / k_{o}\right)$, calculated using Eq. 1, with $k_{w}$ and $k_{s}$ as the mass transfer coefficients in the water and the SR polymer respectively, and $K_{s w}$ the silicone-water partition coefficient [26, 29, 30].

$$
\frac{1}{k_{o}}=\frac{1}{k_{w}}+\frac{1}{K_{s w} k_{s}}
$$


112 According to Greenwood et al. [26] and Huckins et al. [28], the individual mass transfer for a

113 specific compound is related to the ratio of the compound's diffusion coefficient $(D)$ and the

114 thickness $(\delta)$ of each compartment (water or SR, respectively noted with subscripts $w$ and $s$ )

115 contributing to $k_{o}$. The mass-transfer coefficients for each compartment are calculated as

116 follows (Eq. 2 and Eq. 3):

117

$$
k_{s}=\frac{D_{s}}{\delta_{s}},
$$

$$
k_{w}=\frac{D_{w}}{\delta_{w}} .
$$

118 If diffusion occurs from both sides for a plate configuration of a SR-based passive sampler,

119 the barrier thickness $\left(\delta_{S}\right)$ is considered as the half-thickness. Using the very simplified

120 approach of Zhao et al. [31], where a linear concentration profile is assumed within the

121 polymer cylinder or rod configuration, the barrier thickness $\left(\delta_{S}\right)$ is considered as the half-

122 diameter or radius. For the water compartment, the notion of water boundary layer (WBL) of

123 thickness $\delta_{w}$ was assumed for convenience, considering the complexity of the hydrodynamics.

124 In this work, we chose to use a mass transfer resistance model with linear concentration

125 profiles in both the WBL and the SR. It is a simple and approximated model, contrary to the

126 two-phase Fickian model [29] (considering a time-dependent $D_{s}$ and resulting in non-linear

127 diffusion profiles in the polymer) that would lead to more accurate results.

128 Assuming that elimination and uptake of compounds obey first-order kinetics (isotropic

129 exchanges), the uptake of compounds in an SR-based passive sampler over time with constant

130 ambient water concentration (and free of compounds at deployment), is described by Eq. 4:

$$
C_{s}(t)=C_{w} K_{s w}\left(1-\exp \left(-k_{e} t\right)\right)
$$

131 where $C_{s}\left(\mathrm{ng} \mathrm{L}^{-1}\right)$ is the concentration of the compound accumulated in the receiving phase;

$132 C_{w}\left(\mathrm{ng} \mathrm{L}^{-1}\right)$ the concentration of the compound in the water phase, and $t(\mathrm{~d})$ the duration of 
133 exposure. Elimination and uptake rate constants, respectively $k_{e}\left(\mathrm{~d}^{-1}\right)$ and $k_{u}\left(\mathrm{~d}^{-1}\right)$ are linked by

134 a proportional constant $K_{s w}\left(\mathrm{~L} \mathrm{~L}^{-1}\right)$, the silicone-water partition coefficient. It is described by

135 the ratio of concentration at equilibrium of the compound in the sampler $C_{s, e q}\left(\mathrm{ng} \mathrm{L}^{-1}\right)$ to the

136 concentration at equilibrium of the compound in the water phase $C_{w, e q}\left(\mathrm{ng} \mathrm{L}^{-1}\right)$. The

137 elimination rate constant $k_{e}$ is expressed by:

$$
k_{e}=\frac{R_{s}}{K_{s w} V_{s}}=\frac{k_{o} A}{K_{s w} V_{s}},
$$

138 where $V_{s}(\mathrm{~L})$ is the volume of the receiving phase, $R_{s}$ is the sampling rate $\left(\mathrm{L} \mathrm{d}^{-1}\right)$ and $A\left(\mathrm{~cm}^{2}\right)$

139 is the exposed surface area of the sampler. The calculation of time of sorption half-

140 equilibrium $\left(t_{1 / 2}=\ln 2 / k_{e}\right)$ is also used to describe the calibration regime as linear $\left(t<t_{1 / 2}\right)$,

141 curvilinear $\left(t_{1 / 2}<t<4 t_{1 / 2}\right)$ or equilibrium $\left(t>4 t_{1 / 2}\right)$ state for the exposure period $(t)$ [28].

142 Combining Eq. 1, Eq. 2, Eq. 3 and Eq. 5, and neglecting biofilm resistance, $R_{s}$, based on the 143 properties of the compounds, is estimated by:

$$
R_{s}=\frac{A}{\frac{\delta_{w}}{D_{w}}+\frac{\delta_{s}}{K_{s w} D_{s}}} .
$$

\section{Materials and methods}

\subsection{Chemicals}

146 The 24 pesticides selected, including two metabolites, covered a broad polarity range $(0.6<$

$\left.147 \log K_{o w}<5.5\right)$ and were listed in Table 1. Among them, 13 additional deuterated pesticides

148 were used as PRCs (SI-1). Pesticides, PRCs and one internal standard (diuron-d6) used for

149 quantification were purchased from Dr Ehrenstorfer (Augsburg, Germany) and Sigma Aldrich

150 (Saint-Quentin Fallavier, France). Acetone and dichloromethane for pesticide residue

151 analysis, UHPLC grade acetonitrile, ethyl acetate and methanol were purchased from

152 Biosolve (Dieuze, France). LC-MS grade formic acid (purity 98\%) was supplied by Waters 
153 (Guyancourt, France). Ultrapure water was obtained using a Millipore water purification

154 system equipped with an LC-Pak cartridge (Billerica, MA, USA). Nitrogen gas (purity

$15599.995 \%$ ) used for thermal decontamination was purchased from Messer (Saint-Georges-

156 d'Espéranche, France).

\subsection{Passive samplers}

158 The passive samplers used in this study were made of SR shaped into small rods. The shape

159 of rod was preferred to the classic sheet because of the convenience of handling and storage,

160 the lower volume of solvent required for back extraction and the possibility to use

161 thermodesorption (TD)-GC/MS analysis. Translucent SR was obtained as flexible cord from

162 Goodfellow (Lille, France). This SR had been selected in an earlier study for its sorption

163 properties for pesticides [13]. The SR was cut with a clean cutter blade into rods $(20 \times 3 \mathrm{~mm})$,

164 with a surface area of $2.03 \mathrm{~cm}^{2}$ and a volume of $141 \mu \mathrm{L}$. Silicone rubber rods (SR rods) were

165 selected by weight $(165 \mathrm{mg} \pm 2.5 \%, d=1.2)$ to ensure repeatability.

166 Before use, SR rods were chemically and thermally cleaned to remove most residues such as

167 oligomers that could interfere with the instrumental analysis [13]. First the SR rods were

168 chemically conditioned by immersion in dichloromethane/methanol (50/50, v/v) under

169 sonication for $15 \mathrm{~min}$. They were then wiped with a lint-free tissue and dried at $70{ }^{\circ} \mathrm{C}$ for $1 \mathrm{~h}$,

170 and thermally treated in a Gerstel tube conditioner TC (Mülheim a/d Ruhr, Germany) under a

171 nitrogen flow $\left(75 \mathrm{~mL} \mathrm{~min}^{-1}\right)$ with a temperature ramp of $10{ }^{\circ} \mathrm{C} \min ^{-1}$ to $300{ }^{\circ} \mathrm{C}$ maintained

172 constant for $1 \mathrm{~h}$.

173 Cleaned SR rods $(n=34)$ were preloaded with PRCs by agitation at $600 \mathrm{rpm}$ for $48 \mathrm{~h}$ in

$174650 \mathrm{~mL}$ of ultrapure water spiked with a mixture of 13 PRCs (water concentrations ranging

175 from 150 to $220 \mu \mathrm{g} \mathrm{L}^{-1}$ ). The SR rods were then gently rinsed with ultrapure water, dried with

176 a lint-free tissue and stored at $-18{ }^{\circ} \mathrm{C}$ until deployed in the calibration system. Before 
177 deployment each SR rod was inserted into a stainless steel spring $(30 \times 5 \mathrm{~mm}$, wire diameter

$178 \quad 0.4 \mathrm{~mm}$ ) to simplify handling.

\subsection{Characteristics of the calibration system}

180 The calibration system was custom-made (Colas \& Gire, Saint-Genis-les-Ollières, France). It

181 consisted of a stainless steel cylindrical tank (diameter $40 \mathrm{~cm}$, height $35 \mathrm{~cm}$ ), with a stirring

182 system and hooks fixed on the inner wall of the tank at 4 levels, each level enabling the experimenter to expose 8 SR rods or 8 SR dosing sheets (Figure 1). Two copper wire hoops were fitted in the middle of the tank. Eight magnetic stir bars, wrapped in aluminium foil, were fixed on the copper wire between each hook; in this way the SR rods in their springs were retained magnetically at each position. The stainless steel tank was filled with $31.4 \mathrm{~L}$ of

187 tap water and placed in a thermostatic bath at $20^{\circ} \mathrm{C}$. The tank was covered with an aluminium 188 plate to prevent evaporation and photo-degradation in the water compartment. A Tinytag selfrecording thermometer (Gemini Data Loggers Ltd, Chichester, United Kingdom) was

190 immersed in the thermostatic bath to continuously follow the water temperature during the 191 experiment.

192 Stirring was done by a four-blade motor-driven propeller composed of an agitator motor 193 (RZR 2020 Control from Heidolph Instrument, Schwabach, Germany) and a propeller with a 194 diameter of $10 \mathrm{~cm}$ (type R1345 from IKA, Staufen, Germany). The rotation generated a water

195 flow velocity near the SR rod positions (set at 5 and $20 \mathrm{~cm} \mathrm{~s}^{-1}$ ). These flow velocities were 196 measured with a propeller-type current meter (Streamflo430, Nixon, Cheltenham, United

197 Kingdom) in the same way for all positions in the tank. All dimensions of the calibration 198 system are availables in SI-2.

199 Constant concentrations of pesticides of about $1 \mu \mathrm{g} \mathrm{L}^{-1}$ in the water were ensured by two 200 methods. Some polar pesticides (CBZ, CTU, DIU, IMD, IPU, NFZ) (Table 1) were directly 
added to the water using $5 \mathrm{~mL}$ of a highly concentrated solution in acetone. For more apolar pesticides, spiked SR sheets acted as diffusive contaminant sources in the water $[5,10]$. Eight SR sheets $(2 \times 7.5 \times 0.3 \mathrm{~cm}$, Goodfellow $)$ were fixed with hooks at the bottom of the tank.

The total volume of the dosing sheets was 20 times that of the SR rods, ensuring that depletion caused by uptake would be negligible. Before being spiked, the sheets were cleaned by shaking in ethyl acetate and then rinsing in ultrapure water [32]. The quantity of pesticides absorbed by the sheets was assessed with partition coefficients determined by Martin et al. [13]. For the spiking step, the SR sheets were placed in a bottle containing $2.5 \mathrm{~L}$ of ultrapure water contaminated with $5 \mathrm{~mL}$ of highly concentrated pesticide solutions (concentrations ranging from 56 to $923 \mathrm{mg} \mathrm{L}^{-1}$ in acetone) and the bottle was shaken for $72 \mathrm{~h}$ at $300 \mathrm{rpm}$. Before the exposure of PRC preloaded passive samplers, the system was run for $72 \mathrm{~h}$ to allow the stabilization of the pesticide concentrations by reaching equilibrium between water and the spiked sheets for all the compounds (including added polar pesticides).

\subsection{Experimental design}

Two calibration experiments lasting 14 days were performed with SR rods spiked with PRCs to simultaneously follow uptake and elimination of compounds at an effective water flow velocity of $5.5 \pm 2.3 \mathrm{~cm} \mathrm{~s}^{-1}(n=14)$ and $19.9 \pm 3.5 \mathrm{~cm} \mathrm{~s}^{-1}(n=19)$. A total of $20 \mathrm{SR}$ rods were exposed for each experiment. Three SR rods spiked with PRCs were analysed to determine the initial concentrations of PRCs. The first SR rod was removed from the tank 30 min after the beginning of the experiment and then after 1,2, 4, $8 \mathrm{~h}$, and 1, 2, 3, 4, 5, 6, 7, 10, 14 days. Additional triplicates of SR rods were also exposed and analysed to evaluate overall repeatability for both uptake of pesticides and elimination of PRCs. The triplicates of SR rods exposed are detailed in the spreadsheet file (SI-7) compiling results of the calibration experiments. During the experiments, a $10 \mathrm{~mL}$ water sample was taken in an amber flask 
every time a SR rod was collected from the tank to measure concentrations of pesticides. All the SR rods and water samples were stored at $-18{ }^{\circ} \mathrm{C}$ before analysis. Moreover, total organic carbon (TOC) was measured at the start and the end of each experiment in acidified water samples ( $\mathrm{HCl} 2 \mathrm{~N}, 1 \%$, v/v) with TOC analyser (multi N/C® 3100, Analytik Jena) using thermal oxidation $\left(850^{\circ} \mathrm{C}\right)$ and NDIR (Non-Dispersive Infrared) sensor.

\subsection{Analytical procedure}

Pesticides were desorbed from SR rods by chemical extraction according to the protocol developed by Martin et al. [13]. The solvent back-extraction recoveries of this step were between 60 and 98\% depending on the compounds (listed in Table 1). Briefly, SR rods were rinsed with ultrapure water, wiped with lint-free tissue and stored at $-18^{\circ} \mathrm{C}$. Before analysis the pesticides absorbed in the SR rods were desorbed in $200 \mu \mathrm{L}$ of acetonitrile/methanol (50/50) for 15 minutes under sonication. Finally, $40 \mu \mathrm{L}$ of the desorbate was added to $150 \mu \mathrm{L}$ of ultrapure water and $10 \mu \mathrm{L}$ of a diuron-d6 solution $\left(200 \mu \mathrm{g} \mathrm{L}^{-1}\right)$ to prepare the extract for analysis by UHPLC-MS/MS (Nexera X2 UHPLC system, Shimadzu and API 4000, AB

Sciex). For calibration experiments, the analysis of the water samples was performed by direct injection. An aliquot of water of $1 \mathrm{~mL}$ was spiked with diuron-d6 at a concentration of $10 \mu \mathrm{g}$ $\mathrm{L}^{-1}$ as for the SR rod extract analysis. Chromatographic parameters, limit of quantification (LOQ) and settings for MS/MS (SI-1) analysis are reported elsewhere by Martin et al. [13].

\section{Results and discussion}

\subsection{Monitoring of experimental parameters}

During the two 14-day exposure experiments, the mean water temperature recorded was 19.7 $\pm 0.5^{\circ} \mathrm{C}$. Considering two measures per experiment and the results of both experiments, we observed a slight variation of $\mathrm{pH}$, from $7.9 \pm 0.6$ at the start of the calibration to $8.6 \pm 0.1$ at 
248 the end. No influence of $\mathrm{pH}$ on the properties of the selected pesticides or the range of

249 fluctuation was expected. A mean value of TOC for the two experiments was measured at 3.5

$250 \pm 1.1 \mathrm{mg} \mathrm{L}^{-1}(n=4)$.

251 The mean pesticide concentrations in the water of the tank ranged from $0.4 \mu \mathrm{g} \mathrm{L}^{-1}$ to $3.1 \mu \mathrm{g} \mathrm{L}^{-}$

$25{ }^{1}$ (Table 1). We opted to work at higher concentrations for some pesticides (TBZ at $23.9 \mu \mathrm{g} \mathrm{L}^{-}$

$253{ }^{1}$, FNT at $24.1 \mu \mathrm{g} \mathrm{L}^{-1}$ and PCM at $9.6 \mu \mathrm{g} \mathrm{L}^{-1}$ ) that had a higher LOQ or could be partly

254 degraded or absorbed by our experimental calibration system. The concentrations of the 23

255 pesticides remained stable (RSD between $8 \%$ and $27 \%, n=30$ ). By contrast, a higher RSD

256 was obtained for PCM (41\%), which may have been partly degraded (aqueous hydrolysis

$257 D T_{50}$ of PCM: $25 \mathrm{~d}$ ). Nevertheless, the SR sheets added into the tank acted as a contaminant

258 source as expected for the other pesticides. The PRC concentrations in the water of the tank at

259 the end of either experiment were below LOQ.

261 Considering the two experiments, repeatability of sorbed mass on triplicates of SR rods

262 sampled in experiments, expressed as $\operatorname{RSD}(n=3)$, ranged from an average value of $3.6 \%$ for 263 dimethomorph (DMM) to $14.5 \%$ for spiroxamine (SPX), except for PCM (21.5\%). These

264 RSD values take into account the accumulation of target pesticides in the SR rods, the liquid

265 desorption process and the UHPLC-MS/MS analysis. We therefore excluded PCM from this

266 study owing to high variability in uptake into SRs and in the water of the tank (cf. §4.1). All

267 calibration results are detailed in an additional spreadsheet (SI-7).

268 For each pesticide, the concentration factor $\left(C_{s} / C_{w}\right)$ was calculated according to the ratio

269 between the concentration in the $\mathrm{SR} \operatorname{rod}\left(\mathrm{ng} \mathrm{L^{-1 }}\right)$ and the mean concentration in water $\left(\mathrm{ng} \mathrm{L^{-1 }}\right)$

270 from the beginning of the experiment to the same sampling time. The concentration factors of

271 the pesticides for various time periods were fitted to a first order uptake model (Eq. 7 derived 
272 from Eq. 4 and Eq. 5) using $R_{s}$ and $K_{s w}$ as adjustable variables. We optimised the sum of the

273 squared differences between the experimental and calculated values to a minimum using non-

274 linear regression with XLSTAT software (version 2015.3.01.19703). The RSD values of the

275 kinetic parameters were calculated using the derivative of the function for each parameter.

$$
\frac{C_{s}}{C_{w}}(t)=K_{s w}\left(1-\exp \left(-\frac{R_{s} t}{K_{s w} V_{s}}\right)\right)
$$

276 We obtained satisfactory coefficients of determination $\left(r^{2}\right)$ of fitted data with the first order

277 uptake model, ranging from 0.938 to 0.993 . The calculation of parameters $\left(R_{s}, K_{s w}, t_{1 / 2}\right)$ took

278 into account solvent back extraction recoveries determined in Martin et al. [13]. The

279 calculated parameters are detailed in Table 1, and the fitted curves are illustrated in SI- 3 . The

280 constants of elimination of pesticides in uptake experiments $\left(k_{e \text { up }}\right)$ were calculated using their

281 associated $R_{s}$ and $K_{s w}$ values according to Eq. 5 .

282 The times of sorption half-equilibrium $\left(t_{1 / 2}\right)$ ranged from $0.2 \mathrm{~d}$ for DCA, reaching equilibrium 283 very quickly in SR rods, up to nearly $15.2 \mathrm{~d}$ for CPE at $5 \mathrm{~cm} \mathrm{~s}^{-1}$. Comparing DCA properties

284 with DMM, which has an equivalent $\log K_{o w}$, the fast uptake kinetic of DCA may be related to 285 its low molecular volume (121 $\AA^{3}$ and $\log K_{\text {ow }}$ of 2.69). DMM has a larger molecular volume $286\left(342 \AA^{3}\right.$ and $\log K_{\text {ow }}$ of 2.68$)$, and we observed a longer $t_{1 / 2}(6.4 \mathrm{~d})$ at $5 \mathrm{~cm} \mathrm{~s}^{-1}$. Thus, mainly 287 curvilinear and equilibrium patterns were observed for the uptake of pesticides in SR rods at 5 $288 \mathrm{~cm} \mathrm{~s}^{-1}$ for $14 \mathrm{~d}$ exposure. Equilibrium state was reached more frequently in the calibration 289 experiment at $20 \mathrm{~cm} \mathrm{~s}^{-1}$. The impact of flow velocity is discussed in section 4.3.

290 According to low flow velocities measured near passive samplers in freshwaters (close to 5 $291 \mathrm{~cm} \mathrm{~s}^{-1}$ with a deployment system), we found that an in situ exposure duration of $7 \mathrm{~d}$ was a 292 good compromise in this SR rod passive sampler configuration to stay within the linear or 293 curvilinear uptake period for 19 out of 23 pesticides $\left(4 t_{1 / 2}>7 \mathrm{~d}\right.$ except for DCA, FNT, MTC 294 and TBZ). 
Those $t_{1 / 2}$ values are greater than those previously reported for a selection of 19 pesticides

with "Passive SBSE" [4]. The authors obtained a $t_{1 / 2}$ ranging from 1.5 to $4 \mathrm{~d}$ in an experiment with flow velocity at $2.5 \mathrm{~cm} \mathrm{~s}^{-1}$. This difference is because of the use of different geometries (area and volume) between the two passive samplers $\left(A / V=17.0 \mathrm{~cm}^{-1}\right.$ and $14.3 \mathrm{~cm}^{-1}$ respectively for Passive SBSE and SR rod) [9] or differences in diffusion coefficients $\left(D_{s}\right)$.

300 Pesticides potentially diffuse into the half-diameter of SR rods $(1.5 \mathrm{~mm})$, whereas the 301 thickness of the SBSE coating is only $1 \mathrm{~mm}$.

Calculated sampling rates $\left(R_{S}\right)$ for the two experiments are reported in Table 1 with their

The partition coefficients calculated in both experiments were compared with results obtained on the same SR in an earlier study by sorption isotherm experiments reported by Martin et al.

311 [13] (SI-4). For pesticides with $\log K_{s w}<3, K_{s w}$ values obtained in the present study were 1.8 to 8.9 times greater than $K_{s w}$ previously determined. Martin et al. [13] suggested a possible adsorption of the pesticides on the SR following a non-linear sorption isotherm depending on

314 water concentration (Freundlich model). However, $K_{s w}$ Freundlich calculated with the mean

315 concentration in water does not match the $K_{s w}$ values obtained in the present study. This

316 difference could be due to different experimental approaches and calculation methods, or to 317 the influence of water characteristics on adsorption (Evian® water $v$ s. tap water). We adopted $318 K_{s w}$ values derived from Eq. 7 in the experiment at $20 \mathrm{~cm}^{-1}$ as reference values (Table 1), 319 because equilibrium state was reached more frequently in calibration experiments at $20 \mathrm{~cm} \mathrm{~s}^{-1}$ 
than at $5 \mathrm{~cm} \mathrm{~s}^{-1}$ for most pesticides after 14-d exposure (Cf. $\S 4.3$ ), leading to more accurate

321 values.

\subsection{Impact of flow velocity on uptake of pesticides}

As predicted by the theoretical model (Cf. $\S 2.0$ ), a correlation of sampling rate, expressed as

$\log R_{s}$ normalised per $100 \mathrm{~cm}^{2}$, with $\log K_{s w}$ should highlight the control of uptake kinetics by the WBL or by the polymer. This change in transport mechanism was expected for hydrophobic compounds with $\log K_{o w}$ in the range 3.5-5 [11, 33]. For hydrophilic compounds theoretically under polymer control ( $\left.R_{\mathrm{S}} \approx A \mathrm{~K}_{\mathrm{sw}} D_{\mathrm{S}} / \delta_{S}\right), R_{S}$ values were expected to increase with increasing $K_{s w}$. On the contrary, for more hydrophobic compounds, such as PCBs and PAHs (with $\log K_{o w}>3.3$ ) not investigated in the present study, $R_{s}$ values were expected to be constant and slowly decrease with increasing $K_{s w}[5]$, in accordance with WBL control theory $\left(R_{\mathrm{S}} \approx A D_{\mathrm{W}} / \delta_{W}\right)$ (compounds with high $K_{s w}$ also have a lower $D_{w}$ ).

In our experiments (Figure 2), for polar pesticides with a low affinity for SR, we observed that the $R_{s}$ values increased with increasing values of $\log K_{s w}$ up to around 3, whereas for more hydrophobic pesticides, $\mathrm{R}_{\mathrm{s}}$ remained constant irrespective of the $\log K_{s w}$ values.

The plot of $\log R_{s}$ at the two velocities (Figure 2) shows similar $R_{s}$ values for polar pesticides, and highlights a significant separation of the two curves at $\log K_{s w}$ around 3.3, defined as graphical intersection of tangents from both ends, with higher values of $R_{s}$ for the experiments at $20 \mathrm{~cm} \mathrm{~s}^{-1}$. This change in behaviour demonstrates the impact of hydrodynamics on the thickness of the WBL and on $R_{s}$ values. A higher flow velocity leads to a thinner WBL, resulting in an increase in $R_{s}$ proportional to $1 / \delta_{w}$. To our knowledge, this is the first time that the change from polymer control to WBL control for $\log K_{s w}>3.3$ has been experimentally confirmed with polar and non-polar compounds $\left(0.6<\log K_{o w}<5.5\right)$ using different flow 
343

velocities. This result is consistent with those of Assoumani et al. [4], suggesting a WBL

344 control for pesticides with $\log K_{\text {ow }}$ above 3.3 (FNT) in "Passive SBSE" (coated with SR).

4.4 PRCs desorption kinetics: isotropic exchanges?

346 The elimination of PRC obeys first-order kinetics described by:

$$
m_{s}(t)=m_{0} \exp \left(-k_{e P R C} t\right)
$$

347 where $m_{s}(\mathrm{ng})$ is the mass of PRC remaining in the receiving phase of the sampler, and $m_{0}$

348 (ng) is the initial mass of spike PRC in the receiving phase. The repeatability of mass

349 measurement on triplicates of SR rods sampled in experiments was similar for the release of

35013 PRCs and for the uptake of pesticides (RSD from $4.3 \%$ to $12.2 \%$ ). The release of PRCs

351 from the SR rods was fitted by nonlinear regression of PRCs fractions $\left(f=m_{S}(\mathrm{t}) / m_{0}\right)$

352 remaining in the SR rod as a function of exposure time $(t)$ using Eq. 8 (XLSTAT), with the

353 elimination constant $\left(k_{e} P R C\right)$ as an adjustable parameter (fitted curves are available in SI-3).

354 Unlike in uptake experiments, not all coefficients of determination $\left(r^{2}\right)$ were satisfactory

355 (ranging from 0.15 to 0.91). Some PRCs (ATZ-d5, CBZ-d4, IPU-d6, MTC-d6 at $5 \mathrm{~cm} \mathrm{~s}^{-1}$ and

356 CBZ-d4, FNT-d6 at $20 \mathrm{~cm} \mathrm{~s}^{-1}$ ) seemed to obey elimination kinetics with an inflexion point (or

357 two slopes) that could not be described by Eq. 8. This was also observed for some compounds

358 with another passive sampler (POCIS) by Morin et al. [34]. Accordingly only PRCs obeying

359 first order kinetics were considered for the present study and the data for above mentioned

360 PRC were removed.

361 Several hypotheses can be ventured to explain these deviations from the first order kinetic

362 model. Adsorption on SR could be involved instead of absorption for these strongly polar

363 PRCs. Another explanation is that the geometry of SR rods with a half-thickness of $1.5 \mathrm{~mm}$

364 makes them thicker than the silicone plates $(0.25 \mathrm{~mm})$, for which isotropic exchanges have

365 been demonstrated [5]. It is possible that the two-phase Fickian model was more adapted in 
this case with a time-dependency of $D_{s}[29,35]$. It may be that the distribution of PRCs within this thicker SR-based passive sampler was not homogeneous because SR rods were preloaded with PRCs without methanol, which allows fast and homogeneous equilibrium by swelling the polymeric structure [36].

Calculated values of $k_{e} P R C$ for the two experiments are reported in Figure 3. RSD ranged from

$3717 \%$ to $34 \%$ similarly to $k_{e}$ up derived from the uptake experiments.

372 The use of several pairs of deuterated (PRCs) and non-deuterated pesticides allowed direct comparison of the uptake and release processes. We opted to use the graphical comparison of uptake/release instead of checking the equality of elimination constants $\left(k_{e}\right.$ up and $k_{e}$ PRC), due to different calculation methods $\left(k_{e}\right.$ up was calculated from Eq. 5. and $k_{e} P R C$ from Eq. 8. with lower $r^{2}$ ). We considered a confidence interval of $10 \%$ for the intersection of uptake/release:

377 isotropic exchanges were thus validated for an intercept between $40 \%$ and $60 \%$.

378 As shown in Figure 3, curves describing the uptake of CPM and LINU and the release of 379 CPM-d6 and LINU-d6 at $5 \mathrm{~cm} \mathrm{~s}^{-1}$ intersect at about $50 \%$ of the concentration interval, 380 indicating that the exchange process is isotropic. These profiles were observed for the 381 following deuterated analogues: ATC, CPM, CPE, FNT, and LINU (SI-3). Isotropic exchange 382 of FNT and FNT-d6 with "Passive SBSE" was also confirmed by Assoumani et al. [4] by comparison of $k_{e}$ values determined by elimination experiments for the two compounds.

384 Therefore, regarding data at $5 \mathrm{~cm} \mathrm{~s}^{-1}$, the release of the 5 selected PRCs seems pertinent for 385 the correction of $R_{s}$ in in situ applications.

386 In Figure 4, the $\log k_{e} P R C$ at the two flow velocities are plotted against $\log K_{s w}$ of non387 deuterated corresponding pesticides. A change of transport mechanism is again highlighted by 388 a global increase and then a decrease in $k_{e} P R C$ with increasing $K_{s w}$ values. However, in 389 contrast to uptake, no differences in the release of hydrophobic PRCs $\left(k_{e} P R C\right.$ (ATC, CFV, 390 CPM, CPE, DFF) were observed between the two flow velocities studied (Figure 4). This is 
surprising considering the impact of flow velocity on uptake for these hydrophobic pesticides.

The cause of this discrepancy might arise from (i) a non-isotropic exchange for the two velocities or (ii) ill-suited design of the calibration system for the elimination experiments.

The graphical comparison of uptake/release of PRCs at $20 \mathrm{~cm} \mathrm{~s}^{-1}$ showed non-isotropic exchange for all pesticides; the uptake was faster than the release of PRCs (SI-3). The alternative explanation is that the static calibration system design (without continuous renewal of water) was not suited to following elimination kinetics.

Hence it is difficult to conclude on the use of selected deuterated pesticides as PRC candidates in this study to take into account variation of flow velocity for $R_{s}$ correction. Other experiments in continuous flow calibration systems will be needed to validate this statement. Considering these results from PRCs, we propose an alternative method based on an overall resistance to mass transfer model to adjust $R_{s}$ from laboratory experiments to other hydrodynamic conditions by measuring in situ flow velocity.

\subsection{Application of the overall resistance to mass transfer model}

We first applied the overall resistance to mass transfer model on our experimental results. The application of Eq. 6 required knowledge of diffusion parameters $\left(D_{w}\right.$ and $\left.D_{s}\right)$ for the pesticides studied. Diffusion coefficients in water $\left(D_{w}\right)$ were calculated using the method of Hayduk and Laudie [37] from the molar volume of pesticides (SI-5). We chose this method according to the recommendation of the US Environmental Protection Agency and the conclusions of Pintado-Herrera et al. [19]. Experimental $D_{s}$ values in SR are scarce in the literature, and have been estimated only for a few classes of contaminants (PCBs and PAHs [20], PBDEs [18] and emerging contaminants [19]) and unfortunately not determined for pesticides. We therefore opted to estimate $D_{s}$ values for pesticides by simultaneously fitting the data at the two flow 
414 velocities to the overall resistance to mass transfer model. The WBL thickness $\left(\delta_{w}\right)$, not

415 available by direct measurement, was defined as an adjustment factor for the model.

416 To estimate the initial $\delta_{w}$ parameters for the model, we used the approximation of a theoretical

417 WBL control model $\left(R_{s} \approx A D_{w} / \delta_{w}\right)$ with six pesticides that had $\log K_{s w}>3.3$ and were

418 considered in WBL control (FNT, CFV, CPM, SPX, DFF, CPE) for both experiments. We

419 obtained $\delta_{w}$ values of $60 \mu \mathrm{m}$ at $5 \mathrm{~cm} \mathrm{~s}^{-1}\left(\delta_{w 5 \text { ini }}\right)$ and $19 \mu \mathrm{m}$ at $20 \mathrm{~cm} \mathrm{~s}^{-1}\left(\delta_{w 20 \text { ini }}\right)$. These values

420 are in the range of typical values (from a few $\mu \mathrm{m}$ to $1 \mathrm{~mm}$ ) reported by Huckins et al. [28] for

421 SPMD.

422 We then used $R_{s}$ and $K_{s w}$ for all pesticides at the two flow velocities $(n=48)$ to calculate more 423 accurate $\delta_{w}$ values ( $\delta_{w}$ and $\left.\delta_{w 2}\right)$ and $D_{s}$ values for 23 pesticides according to Eq. 6. Predicted $424 R_{S}$ values were fitted simultaneously to the experimental $R_{S}$ values with adjustable parameters 425 ( $\delta_{w}$ values and $D_{s}$ values) by minimising the sum of the squares of the residuals weighted by 426 the average of the residuals with the "optim" function of R software (version 2.15.2) and a 427 limited memory algorithm for bound constrained optimisation (L-BFGS-B). The initial values 428 of adjustable parameters were $\delta_{w \text { ini }}$ values and a $\log D_{s}$ value of $-11 \mathrm{~m}^{2} \mathrm{~s}^{-1}$ for all pesticides 429 (approximated mean value for PAHs and PCBs as initial parameters), and lower and upper 430 bounds were respectively 0 and $1000 \mathrm{~mm}$ for $\delta_{w}$, and -10 and -14 for $\log D_{s}$.

431 Predicted $R_{s}$ values (normalised to $100 \mathrm{~cm}^{2}$ ) adjusted to our experimental data were plotted 432 against $\log K_{s w}$ (Figure 5). Estimated $\delta_{w}$ values $\left(\delta_{w 5}=43 \mu \mathrm{m}\right.$ and $\left.\delta_{w 20}=10 \mu \mathrm{m}\right)$ were slightly 433 lower than those evaluated initially. Estimated $\log D_{s}$ for pesticides are given in Table 1.

434 Estimated $\log D_{s}$ values in the present study were in the range -12.13 (IMD) to -10.07 (CPE) $435 \mathrm{~m}^{2} \mathrm{~s}^{-1}$. The lowest $\log D_{s}$ for pesticides $\left(-12.13 \mathrm{~m}^{2} \mathrm{~s}^{-1}\right)$ was for IMD, the most hydrophilic 436 compound studied $\left(\log K_{o w}=0.6\right)$ with the lowest affinity for SR $\left(\log K_{s w}=0.71\right)$. By 437 contrast, the highest $\log D_{s}$ was for CPE, the second most hydrophobic pesticide $\left(\log K_{o w}=\right.$ 
438 4.7) with the highest affinity for SR $\left(\log K_{s w}=4.60\right)$. The most hydrophobic pesticide, SPX

$439\left(\log K_{o w}=5.5\right)$, also had a high molar volume reported to influence the diffusion of

440 compounds in polymers [20,38] and resulting in a decreased diffusivity in SR. Other trends

441 of the diffusion coefficients related to chemical structures are illustrated in SI-6 with $\log D_{s}$

442 plotted to molar volumes and molar mass.

443 This is a first evaluation of $D_{s}$ values for pesticides using calibration data instead of direct

444 measurement. They therefore need to be validated with further experiments. In regard to other

445 experimental values for PAHs and PCBs for another SR formulation (supplied by Altec) [20],

446 ranging from -9.8 to $-11.0 \mathrm{~m}^{2} \mathrm{~s}^{-1}$; our data seem reasonable. In comparison, diffusion

447 coefficient values for the studied pesticides were lower and with a wider range ( 2 orders of

448 magnitude) than for PCBs and PAHs (1 order of magnitude).

4.6 Modelling of the influence of water flow velocity on sampling rates

450 The knowledge of $D_{s}$ for each pesticide and $\delta_{w}$ values related to flow velocity enabled us to

451 estimate $R_{s}$ for other hydrodynamic conditions. Also, the change from the polymer control to

452 the WBL control could be predicted. This model aims at estimating $\delta_{w}$ by a correlation related

453 to a hydrodynamic parameter such as water flow velocity. Such a correlation was proposed by

454 Estoppey et al. [7, 8] for PCBs by in situ passive sampler exposures using LDPE and SR

455 plates.

456 Our estimated $\delta_{w}$ values for two different measured flow velocities were insufficient to

457 demonstrate such a correlation; we therefore used calibration data for which water flow

458 velocities were only estimated to determine complementary $\delta_{w}$ values. The study of Rusina et

459 al. [5] describes calibration experiments for PAHs and PCBs with SR flat plate passive

460 samplers at two calculated flow velocities ( $\operatorname{Exp~} A=0.14 \mathrm{~cm} \mathrm{~s}^{-1}$ and $\left.\operatorname{Exp~B}=9 \mathrm{~cm} \mathrm{~s}^{-1}\right)$,

461 assuming that uptake was controlled by diffusion in the WBL in both cases. We applied the 
462

463

464

465

466

467

468

469

470

471

472

473

474

475

476

477

478

479

480

481

482

483

484

485

486

overall resistance to mass transfer model with the available experimental values of $D_{s}$ for PAHs and PCBs [20]. The estimated $\delta_{w}$ values were $\delta_{w 0.1}=412 \mu \mathrm{m}$ and $\delta_{w}=27 \mu \mathrm{m}$. In quasi-static hydrodynamics conditions $\left(0.14 \mathrm{~cm} \mathrm{~s}^{-1}\right)$, the WBL thickness was more than 7 times greater than at $5 \mathrm{~cm} \mathrm{~s}^{-1}$ in our experiment.

The estimated $\delta_{w}$ values from the two studies $(n=4)$ were plotted against the flow velocities (v) reported in experiments in Figure 6. A power function correlation was observed between $\delta_{w}$ values and $v\left(n=4, \delta_{w}=111.6 v^{-0.71}, r^{2}=0.98\right)$. Such a correlation was indirectly demonstrated by Estoppey et al. [7] with power function relations between amounts of PCB accumulated and flow velocity in the range 1.9 to $37.7 \mathrm{~cm} \mathrm{~s}^{-1}$. They then provided individual linear correlations for 6 PCBs between PRC-based $R_{s}$ and water flow velocities above $10 \mathrm{~cm}$ $\mathrm{S}^{-1}$ for SR: assuming that PCB uptake was under WBL control, the $R_{s}$ is proportional to $1 / \delta_{w}$, which was indirectly linked to $v$. Our results confirm that this relationship could also be approximated by a linear correlation for flow velocities above $5 \mathrm{~cm} \mathrm{~s}^{-1}\left(n=3, \delta_{w}=-2.1 v+\right.$ $\left.51, r^{2}=0.93\right)$.

These results acquired using different SR based passive sampler designs (plate or cylinder) suggest that the effect of flow velocity on the water boundary layer thickness calculated from Eq.6 could be weakly influenced by the geometry of the passive samplers used. Considering the complexity of hydrodynamic conditions near a passive sampler, and the different positions of the passive sampler in the fluid, this approximation yields a simple model that will need to be validated with further data including measurement of water flow velocities.

In Figure 5, we calculated $R_{s}$ values for pesticides with SR rods at flow velocities recorded by Rusina et al. [5]. At low flow velocity $\left(v=0.14 \mathrm{~cm} \mathrm{~s}^{-1}\right)$, the estimated $R_{S}$ values for WBL controlled pesticides $\left(\log K_{s w}>2.7\right)$ were lower by a mean factor of 10 than those experimentally determined at $5 \mathrm{~cm} \mathrm{~s}^{-1}$, and the change in transport mechanism occurred at log $K_{s w}$ around 2.7 instead of 3.3. These extrapolated data could be used to calculate time- 
487

weighted average concentrations of pesticides in freshwaters with only a representative field measurement of water flow velocity. Another way to calculate $\delta_{w}$ could be to use an adaptation of the PRCs model with deuterated PAHs or PCBs as described by Booij et al. [36].

\section{Conclusion}

The calibration data for SR rods, $R_{s}$ and $K_{s w}$ were determined for 23 pesticides and 13 candidate PRCs in a laboratory calibration system over $14 \mathrm{~d}$ at two flow velocities. The results show that an in situ exposure duration of $7 \mathrm{~d}$ kept the SR rod passive sampler configuration in the linear or curvilinear uptake period for 19 pesticides. A change in transport mechanism from polymer control to WBL control was observed for a $\log K_{s w}$ of around 3.3. The isotropic exchange of candidate PRCs was demonstrated for 5 PRCs at $5 \mathrm{~cm} \mathrm{~s}^{-1}$. However, the influence of water flow velocity on elimination was not demonstrated. Hence, the use of these PRCs was not validated to correct $R_{s}$ for pesticides with WBL-controlled uptake kinetics.

Considering the PRC results, we propose an alternative method based on the overall resistance to mass transfer model to adjust $R_{s}$ from laboratory experiments to other hydrodynamic conditions by measuring in situ flow velocities. The theoretical model of overall resistance to mass transfer was applied to our experimental data using $\log D_{s}$ values and $\delta_{w}$ as adjustable parameters. The estimated $\log D_{s}$ values ranging from -12.13 to -10.07 $\mathrm{m}^{2} \mathrm{~s}^{-1}$ for pesticides were consistent with values previously determined for PAHs and PCBs. Nonetheless, the application of a two-phase Fickian model could lead to more accurate results; for this purpose, calibration results are detailed in an additional spreadsheet (SI-7). Moreover, we demonstrated a power function correlation between $\delta_{w}$ and water velocity using a compilation of data from the present study and from Rusina et al. [5]. This correlation is 
apparently not influenced by passive sampler geometry. Thus, the estimation of new $R_{s}$

requires only direct measurements of flow velocity in the deployment location of the SR-

\section{Acknowledgments}

The authors thank Claire Lauvernet (Irstea) for help in R script programing and Matthieu

518 Masson's team (Irstea) for analysis of water. This work was funded by the French Agency for

\section{References}

1. Rabiet M, Margoum C, Gouy V, Carluer N, Coquery M. 2010. Assessing pesticide concentrations and fluxes in the stream of a small vineyard catchment-effect of sampling frequency. Environ. Pollut. 158:737-748.

2. Poulier G, Lissalde S, Charriau A, Buzier R, Delmas F, Gery K, Moreira A, Guibaud G, Mazzella N. 2014. Can POCIS be used in Water Framework Directive (2000/60/EC) monitoring networks? A study focusing on pesticides in a French agricultural watershed. Sci. Total Environ.. 497-498:282-292.

3. Miège C, Mazzella N, Allan I, Dulio V, Smedes F, Tixier C, Vermeirssen E, Brant J, O'Toole S, Budzinski H, Ghestem J-P, Staub P-F, Lardy-Fontan S, Gonzalez J-L, Coquery M, Vrana B. 2015. Position paper on passive sampling techniques for the monitoring of contaminants in the aquatic environment - Achievements to date and perspectives. Trends Anal. Chem. 8:20-26.

4. Assoumani A, Margoum C, Chataing S, Guillemain C, Coquery M. 2014. Use of passive stir bar sorptive extraction as a simple integrative sampling technique of pesticides in freshwaters: determination of sampling rates and lag-phases. $J$. Chromatogr. A. 1333:1-8.

5. Rusina TP, Smedes F, Koblizkova M, Klanova J. 2010. Calibration of Silicone Rubber Passive Samplers: Experimental and Modeled Relations between Sampling Rate and Compound Properties. Environ. Sci. Technol. 44:362-367.

6. Vrana B, Komancova L, Sobotka J. 2016. Calibration of a passive sampler based on stir bar sorptive extraction for the monitoring of hydrophobic organic pollutants in water. Talanta. 152:90-97. 
7. Estoppey N, Schopfer A, Omlin J, Esseiva P, Vermeirssen ELM, Delémont O, De Alencastro LF. 2014. Effect of water velocity on the uptake of polychlorinated biphenyls (PCBs) by silicone rubber (SR) and low-density polyethylene (LDPE) passive samplers: An assessment of the efficiency of performance reference. compounds (PRCs) in river-like flow conditions. Sci. Total Environ. 499:319-326.

8. Estoppey N, Schopfer A, Fong C, Delemont O, De Alencastro LF, Esseiva P. 2016. An in-situ assessment of low-density polyethylene and silicone rubber passive samplers using methods with and without performance reference compounds in the context of investigation of polychlorinated biphenyl sources in rivers. Sci. Total Environ. 572:794-803.

9. Belles A, Alary C, Mamindy-Pajany Y. 2016. Thickness and material selection of polymeric passive samplers for polycyclic aromatic hydrocarbons in water: Which more strongly affects sampler properties? Environ. Toxicol. Chem. 35:1708-1717.

10. Jacquet R, Miege C, Smedes F, Tixier C, Tronczynski J, Togola A, Berho C, Valor I, Llorca J, Barillon B, Marchand P, Coquery M. 2014. Comparison of five integrative samplers in laboratory for the monitoring of
biphenyls in water. Chemosphere. 98:18-27.

11. Allan IJ, Booij K, Paschke A, Vrana B, Mills GA, Greenwood R. 2010. Short-term exposure testing of six different passive samplers for the monitoring of hydrophobic contaminants in water. J. Environ. Monit. 12:696-703.

12. Schellin M, Popp P. 2007. Application of a polysiloxane-based extraction method combined with large volume injection-gas chromatography-mass spectrometry of organic compounds in water samples. J. Chromatogr. A. 1152:175-183.

13. Martin A, Margoum C, Randon J, Coquery M. 2016. Silicone rubber selection for passive sampling of pesticides in water. Talanta. 160:306-313.

14. Heltsley RM. 2004. Novel methods for monitoring chlorinated contaminants in aquatic environments. PhD thesis. Department of environmental and molecular toxicology. North Carolina State University, US.

15. Kwon JH, Wuethrich T, Mayer P, Escher BI. 2007. Dynamic permeation method to determine partition coefficients of highly hydrophobic chemicals between poly(dimethylsiloxane) and water. Anal. Chem. 79:6816-6822.

16. Magner JA, Alsberg TE, Broman D. 2009. Evaluation of poly(ethylene-co-ninyl acetate-co-carbon monoxide) and polydimethylsiloxane for equilibrium sampling of polar organic contaminants in water. Environ. Toxicol. Chem. 28:1874-1880.

17. Ahrens L, Daneshvar A, Lau AE, Kreuger J. 2015. Characterization of five passive sampling devices for monitoring of pesticides in water. J. Chromatogr. A. 1405:1-11.

18. Narvaez Valderrama JF, Baek K, Molina FJ, Allan IJ. 2016. Implications of observed PBDE diffusion coefficients in low density polyethylene and silicone rubber. Environ. Sci.: Processes Impacts. 18:87-94.

19. Pintado-Herrera MG, Lara-Martin PA, Gonzalez-Mazo E, Allan IJ. 2016. Determination of silicone rubber and low-density polyethylene diffusion and polymer/water partition coefficients for emerging contaminants. Environ. Toxicol. Chem. 35:2162-2172.

20. Rusina TP, Smedes F, Klanova J. 2010. Diffusion Coefficients of Polychlorinated Biphenyls and Polycyclic Aromatic Hydrocarbons in Polydimethylsiloxane and LowDensity Polylethylene Polymers. J. Appl. Polym. Sci. 116:1803-1810.

21. Jonker MTO, van der Heijden SA, Kotte M, Smedes F. 2015. Quantifying the Effects of Temperature and Salinity on Partitioning of Hydrophobic Organic Chemicals to Silicone Rubber Passive Samplers. Environ. Sci. Technol. 49:6791-6799. 
22. Booij K, van Bommel R, Mets A, Dekker R. 2006. Little effect of excessive biofouling on the uptake of organic contaminants by semipermeable membrane devices. Chemosphere. 65:2485-2492.

23. Allan IJ, Harman C, Kringstad A, Bratsberg E. 2010. Effect of sampler material on the uptake of PAHs into passive sampling devices. Chemosphere. 79:470-475.

24. Booij K Smedes F. 2010. An Improved Method for Estimating in Situ Sampling Rates of Nonpolar Passive Samplers. Environ. Sci. Technol. 44:6789-6794.

25. O'Brien D, Komarova T, Mueller JF. 2012. Determination of deployment specific chemical uptake rates for SPMD and PDMS using a passive flow monitor. Mar. Pollut. Bull.. 64:1005-1011.

26. Greenwood R, Mills G, Vrana B. 2007. Passive Sampling Techniques in Environmental Monitoring, 1st Edition. Elsevier, Amsterdam, The Netherlands.

27. Emelogu ES, Pollard P, Robinson CD, Webster L, McKenzie C, Napier F, Steven L, Moffat CF. 2013. Identification of selected organic contaminants in streams associated with agricultural activities and comparison between autosampling and silicone rubber passive sampling. Sci. Total Environ. 445:261-272.

28. Huckins JN, Petty JD, Booij K. 2006. Monitors of Organic Chemicals in the Environment. Semipermeable Membrane Devices. Springer, New York NY, USA.

29. Tcaciuc AP, Apell JN, Gschwend PM. 2015. Modeling the transport of organic chemicals between polyethylene passive samplers and water in finite and infinite bath conditions. Environ. Toxicol. Chem. 34:2739-2749.

30. Allan IJ, Harman C, Ranneklev SB, Thomas KV, Grung M. 2013. Passive sampling for target and nontarget analyses of moderately polar and nonpolar substances in water. Environ. Toxicol. Chem. 32:1718-1726.

31. Zhao WN, Ouyang GF, Alaee M, Pawliszyn J. 2006. On-rod standardization technique for time-weighted average water sampling with a polydimethylsiloxane rod. $J$. Chromatogr. A. 1124:112-120.

32. Rusina TP, Smedes F, Klanova J, Booij K, Holoubek I. 2007. Polymer selection for passive sampling: a comparison of critical properties. Chemosphere. 68:1344-1351.

33. Allan IJ, Booij K, Paschke A, Vrana B, Mills GA, Greenwood R. 2009. Field performance of seven passive sampling devices for monitoring of hydrophobic substances. Environ. Sci. Technol. 43:5383-5390.

34. Morin N, Camilleri J, Cren-Olivé C, Coquery M, Miège C. 2013. Determination of uptake kinetics and sampling rates for 56 organic micropollutants using “pharmaceutical” POCIS. Talanta. 109:61-73.

35. Thompson JM, Hsieh C-H, Luthy RG. 2015. Modeling uptake of hydrophobic organic contaminants into polyethylene passive samplers. Environ. Sci. Technol. 49:22702277.

36. Booij K, Smedes F, van Weerlee EM. 2002. Spiking of performance reference compounds in low density polyethylene and silicone passive water samplers. Chemosphere. 46:1157-1161.

37. Hayduk W, Laudie H. 1974. Prediction of diffusion coefficients for nonelectrolytes in dilute aqueous solutions. AIChE Journal. 20:611-615.

38. ter Laak TL, Busser FJ, Hermens JL. 2008. Poly(dimethylsiloxane) as passive sampler material for hydrophobic chemicals: effect of chemical properties and sampler characteristics on partitioning and equilibration times. Anal. Chem. 80:3859-3866. 
641 Figure 1. Schematic diagram of the laboratory static calibration system (a), depiction of the

642 inside of the calibration tank with the SR rods (b) and zoom on SR-rods inserted in a spring

643 (c)

644

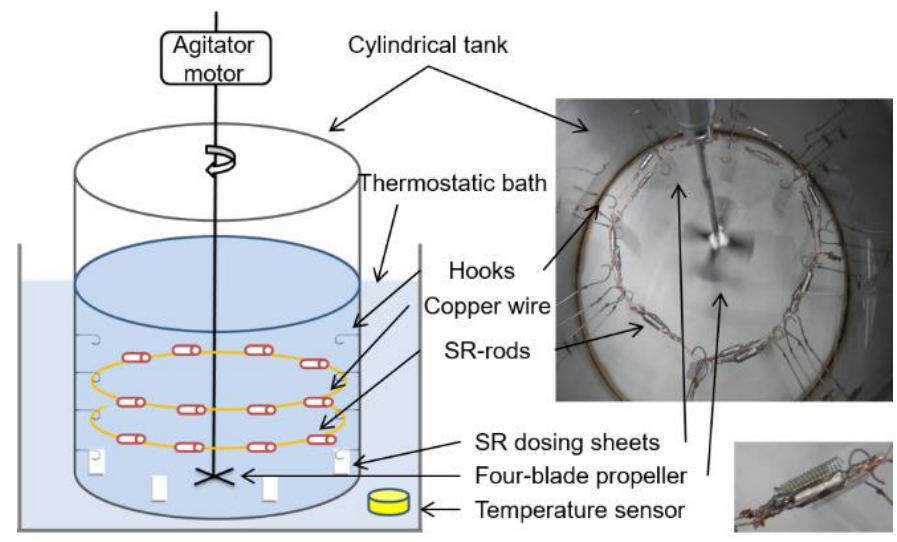

645 
646 Figure 2. Plot of $\log R_{s}$ normalised per $100 \mathrm{~cm}^{2}$ versus $\log K_{s w}$ in our experiment at two flow

647 velocities. Error is expressed as standard deviation.

648

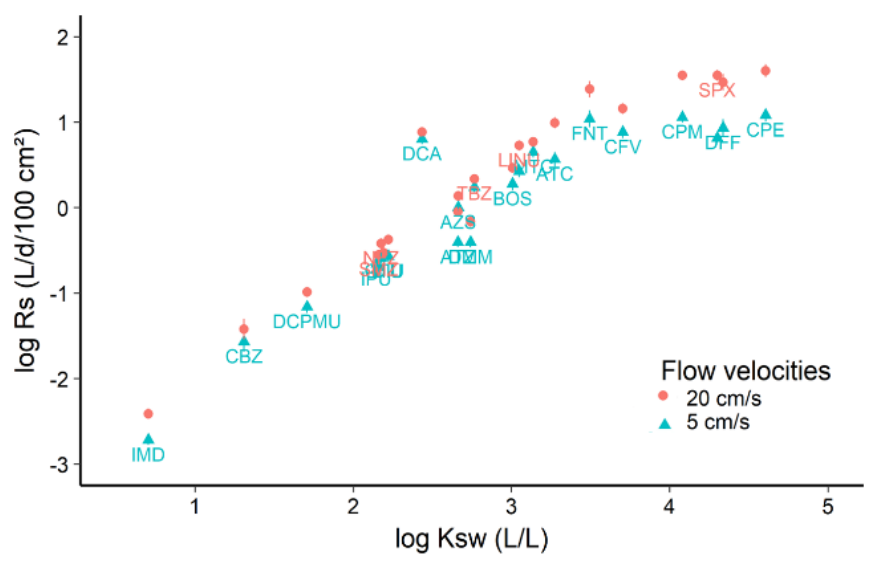

649 
650 Figure 3. The uptake of CPM and LINU and release of corresponding deuterated pesticides

651 (CPM-d6 and LINU-d6) by SR rods. Mass ratios are plotted relative to the initial mass for the

652 release $\left(m_{0}\right)$ and to the predicted equilibrium mass for the uptake $\left(m_{e q}\right)$ with triangles for $5 \mathrm{~cm}$

$653 \mathrm{~s}^{-1}$ and circles for $20 \mathrm{~cm} \mathrm{~s}^{-1}$.

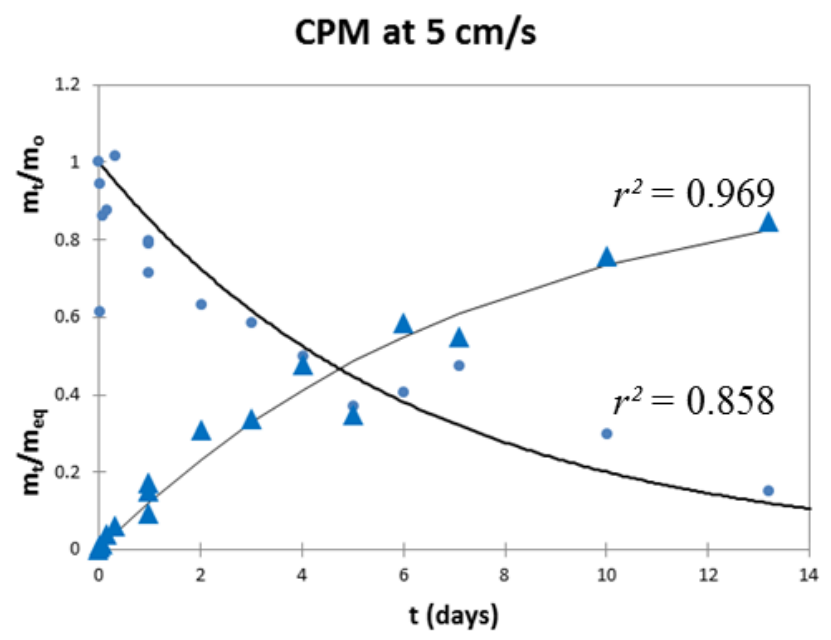

- CPMD-d6 - Elimination model $\triangle$ CPM — Uptake model

LINU at $5 \mathrm{~cm} / \mathrm{s}$

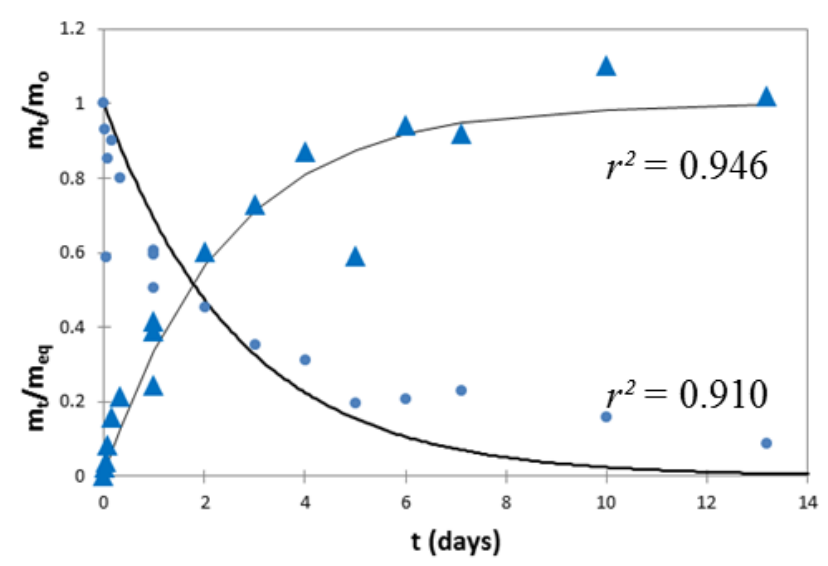

654

- LINU-d6 —Elimination model $\Delta$ LINU — Uptake model 
656 Figure 4. Plot of $\log k_{e} P R C$ versus $\log K_{s w}$ in experiments at two flow velocities ( 5 and $20 \mathrm{~cm}$ $\left.657 \mathrm{~s}^{-1}\right)$.

658

\begin{tabular}{|c|c|c|c|c|c|c|c|}
\hline \multicolumn{8}{|c|}{$\log K_{s w}\left(\mathrm{~L} \mathrm{~L}^{-1}\right)$} \\
\hline 1.5 & 2.0 & 2.5 & 3.0 & 3.5 & 4.0 & 4.5 & 5.0 \\
\hline & \multirow{2}{*}{\multicolumn{2}{|c|}{$\begin{array}{l}\Delta \log \text { ke } P R C \text { at } 5 \mathrm{~cm} / \mathrm{s} \\
\text { O log ke } P R C \text { at } 20 \mathrm{~cm} / \mathrm{s}\end{array}$}} & & & & & \\
\hline-0.2 & & & $\Delta$ & & & & \\
\hline-0.4 & & & $\stackrel{\text { INU-d6 }}{\circ} 8$ & FNT-d 6 & & & \\
\hline${\frac{F^{2}}{\sigma}}^{0.6}$ & & & ATC-d1 & & $\begin{array}{l}\text { O } \\
\Delta\end{array}$ & & \\
\hline$\underbrace{0.8}$ & & & 0 & & & & \\
\hline$\stackrel{\infty}{0}_{-1}$ & $\underset{\text { SMZ-dS }}{\Delta}$ & $\underset{\text { TBZ-d6 }}{\theta}$ & MTC-d6 & oै & & $\Delta$ & \\
\hline-1.2 & $\begin{array}{c}8 \\
\text { IPU-d6 }\end{array}$ & $\underset{\text { ATZ-d5 }}{0}$ & & CFV-d10 & & $\underset{\text { CPE-d10 }}{\stackrel{0}{-d}}$ & \\
\hline $\begin{array}{l}-1.4 \\
-1.6\end{array}$ & & & & & & & \\
\hline
\end{tabular}

659 
660 Figure 5. Plot of $\log R_{s}$ normalised per $100 \mathrm{~cm}^{2}$ versus $\log K_{s w}$ in experiments at two flow

661 velocities ( 5 and $20 \mathrm{~cm} \mathrm{~s}^{-1}$ ) with theoretical model (solid lines) and estimated by theoretical

662 model (dotted lines) for other flow velocities $\left(0.14\right.$ and $9 \mathrm{~cm} \mathrm{~s}^{-1}$ with data from Rusina et al.

$663[5])$.

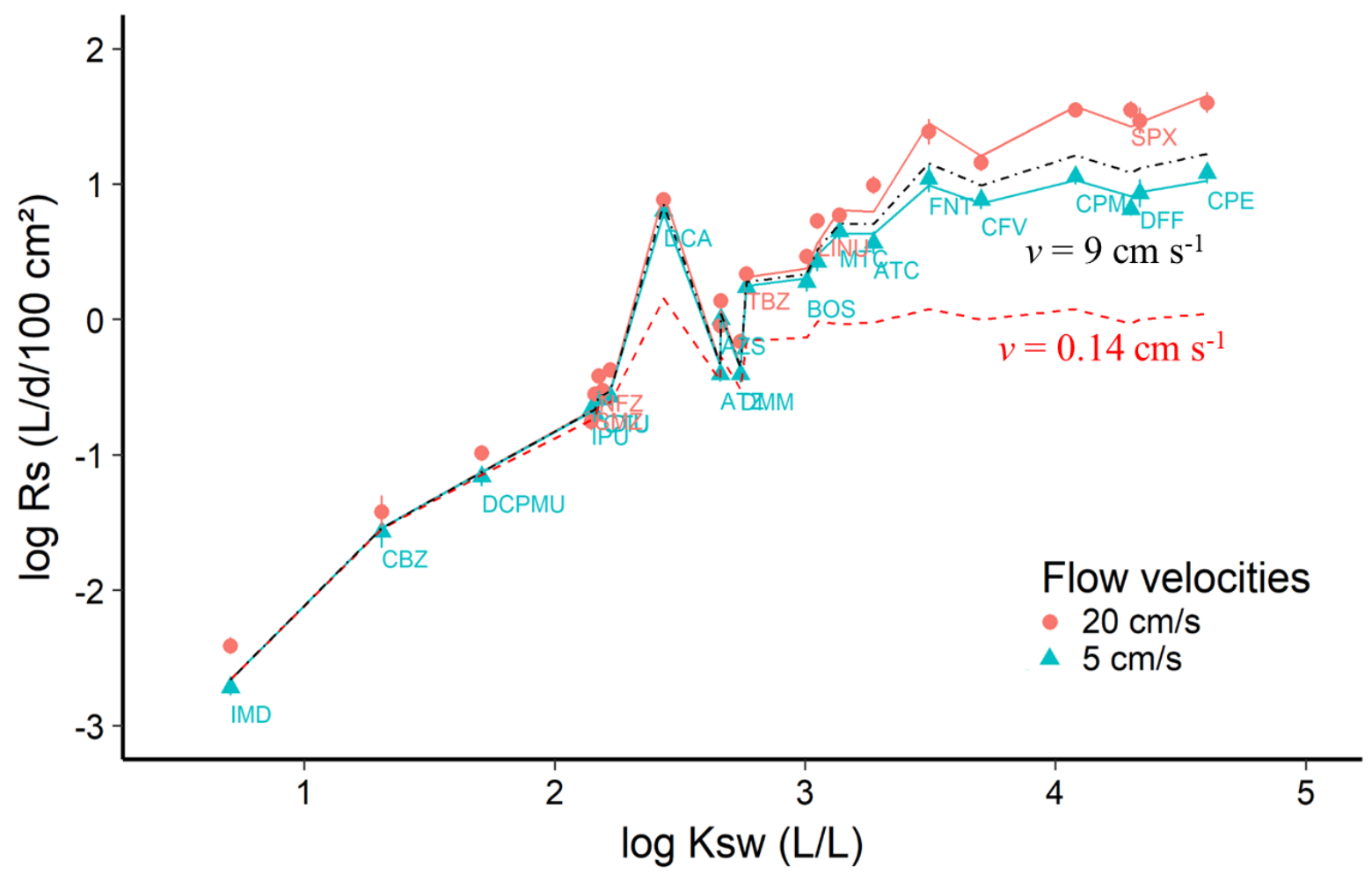

664 
666 Figure 6. Plot of water boundary layer thickness $\left(\delta_{w}\right)$ estimated by theoretical model (Eq. 6)

667 versus water flow velocity ( $v$ ) from this present study (circles) and Rusina et al. [5] (crosses).

668

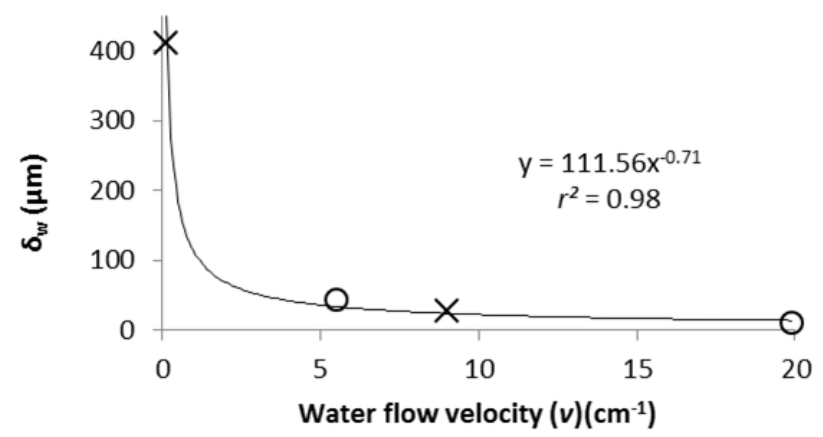


669 Table 1. Physico-chemical properties, kinetic parameters at two flow velocities and estimated diffusion coefficients of the 670 studied pesticides.

\begin{tabular}{|c|c|c|c|c|c|c|c|c|c|c|c|}
\hline Pesticide name & Abbreviation & $\log K_{o w}{ }^{a}$ & $\begin{array}{l}\text { Water concentration } \\
\left(\mu \mathrm{g} \mathrm{L}^{-1}\right)\end{array}$ & $\begin{array}{c}\text { Solvent back } \\
\text { extraction } \\
\text { recovery }(\%) \\
\end{array}$ & $\begin{array}{c}\log K_{s w} \\
\left(\mathbf{L} \mathbf{L}^{-1}\right)\end{array}$ & $\begin{array}{c}\log K_{s w} \\
\left(\mathbf{L} \mathbf{L}^{-1}\right)\end{array}$ & $\begin{array}{c}\boldsymbol{R}_{s} \\
\left(\mathbf{m L ~ d ^ { - 1 }}\right)\end{array}$ & $\begin{array}{c}\boldsymbol{R}_{s} \\
\left(\mathbf{m L ~ d ^ { - 1 }}\right)\end{array}$ & $\begin{array}{l}t_{1 / 2} \\
(d)\end{array}$ & $\begin{array}{l}t_{1 / 2} \\
\text { (d) }\end{array}$ & $\begin{array}{l}\log D_{s} \\
\left(m^{2} s^{-1}\right)\end{array}$ \\
\hline & & & $\begin{array}{c}\text { Mean value } \\
n=30, \operatorname{RSD}(\%)\end{array}$ & $\begin{array}{c}\text { Mean value } \\
n=3, \mathrm{sd}\end{array}$ & $\begin{array}{c}5 \mathbf{c m ~ s}^{-1} \\
n=20, \mathrm{sd}\end{array}$ & $\begin{array}{l}20 \mathbf{c m ~ s}^{-1} \\
n=20, \mathrm{sd}\end{array}$ & $\begin{array}{c}\mathbf{5} \mathbf{c m ~ s}^{-1} \\
n=20, \operatorname{RSD}(\%)\end{array}$ & $\begin{array}{c}\mathbf{2 0} \mathbf{c m ~ s}^{-1} \\
n=20, \operatorname{RSD}(\%)\end{array}$ & $5 \mathrm{~cm} \mathrm{~s}^{-1}$ & $20 \mathrm{~cm} \mathrm{~s}^{-1}$ & $\begin{array}{c}\text { Estimated } \\
\text { values }\end{array}$ \\
\hline Acetochlor & ATC & 4.1 & $2.8(13)$ & $69(9)$ & $3.18(0.03)$ & $3.27(0.01)$ & $75(19)$ & $200(14)$ & 2.3 & 0.9 & -11.17 \\
\hline Atrazine & ATZ & 2.7 & $1.5(24)$ & $86(4)$ & $2.47(0.04)$ & $2.66(0.02)$ & $8.0(12)$ & $18(8)$ & 5.3 & 2.3 & -11.75 \\
\hline Azoxystrobin & AZS & 2.5 & $1.2(15)$ & $95(6)$ & $2.87(0.03)$ & $2.66(0.02)$ & $20(10)$ & $28(10)$ & 2.1 & 1.5 & -11.35 \\
\hline Boscalid & BOS & 3.0 & $1.8(16)$ & $80(7)$ & $2.89(0.03)$ & $3.01(0.02)$ & $38(16)$ & $59(12)$ & 2.4 & 1.6 & -11.36 \\
\hline Carbendazim & $\mathrm{CBZ}$ & 1.5 & $0.4(16)$ & $82(21)$ & $1.41(0.04)$ & $1.31(0.03)$ & $0.5(27)$ & $0.8(27)$ & 3.4 & 2.4 & -11.61 \\
\hline Chlorfenvinphos & $\mathrm{CFV}$ & 3.8 & $2.7(9)$ & $82(10)$ & $3.82(0.04)$ & $3.70(0.01)$ & $155(16)$ & $293(14)$ & 3 & 1.6 & -11.05 \\
\hline Chlorpyrifos-ethyl & CPE & 4.7 & $1.6(14)$ & $60(10)$ & - & $4.60(0.03)$ & $245(17)$ & $812(17)$ & 15.2 & 4.6 & -10.07 \\
\hline Chlorpyrifos-methyl & CPM & 4 & $1.9(12)$ & $68(6)$ & $4.12(0.05)$ & $4.08(0.01)$ & $231(13)$ & $714(10)$ & 4.8 & 1.5 & -10.67 \\
\hline Chlortoluron & CTU & 2.5 & $1.8(11)$ & $90(9)$ & $1.76(0.02)$ & $2.19(0.01)$ & $5.5(17)$ & $6.1(12)$ & 2.6 & 2.4 & -11.50 \\
\hline 3.4-dichloroaniline & DCA & 2.7 & $0.9(20)$ & $87(6)$ & $2.19(0.01)$ & $2.43(0.01)$ & $129(13)$ & $156(11)$ & 0.2 & 0.2 & -10.20 \\
\hline $\begin{array}{l}\text { 3-(3.4-dichlorophenyl)- } \\
\text { 1-methylurea }\end{array}$ & DCPMU & $2.9^{*}$ & 1.5 (19) & $91(10)$ & $1.53(0.03)$ & $1.71(0.02)$ & $1.4(16)$ & $2.1(13)$ & 3.4 & 2.2 & -11.59 \\
\hline Diflufenican & DFF & 4.2 & $1.4(15)$ & $69(15)$ & $4.37(0.14)$ & $4.34(0.02)$ & $174(24)$ & $598(22)$ & 11.5 & 3.3 & -11.15 \\
\hline Diuron & DIU & 2.9 & $2.0(12)$ & $87(8)$ & $2.13(0.03)$ & $2.22(0.02)$ & $5.5(16)$ & $8.6(13)$ & 2.8 & 1.8 & -11.50 \\
\hline Dimethomorph & DMM & 2.7 & $1.8(16)$ & $96(12)$ & $2.81(0.04)$ & $2.74(0.02)$ & $8.0(14)$ & $14(14)$ & 6.4 & 3.7 & -11.84 \\
\hline Fenitrothion & FNT & 3.3 & $24.1(15)$ & $76(13)$ & $3.37(0.02)$ & $3.49(0.01)$ & $222(22)$ & $495(21)$ & 1.3 & 0.6 & -10.45 \\
\hline Imidacloprid & IMD & 0.6 & $1.1(8)$ & $91(11)$ & $0.42(0.04)$ & $0.71(0.04)$ & $0.04(13)$ & $0.08(13)$ & 12 & 5.9 & -12.13 \\
\hline Isoproturon & IPU & 2.5 & $1.8(11)$ & $96(12)$ & $2.22(0.03)$ & $2.15(0.02)$ & $4.4(16)$ & $3.6(13)$ & 2.9 & 3.6 & -11.58 \\
\hline Linuron & LINU & 3.0 & $3.1(13)$ & $73(6)$ & $2.99(0.03)$ & $3.05(0.01)$ & $54(16)$ & 109 (13) & 1.9 & 0.9 & -11.21 \\
\hline Metolachlor & MTC & 3.4 & $2.2(10)$ & $75(5)$ & $3.17(0.02)$ & $3.14(0.01)$ & $91(14)$ & $120(10)$ & 1.4 & 1.1 & -11.02 \\
\hline Norflurazon & NFZ & 2.5 & $1.9(17)$ & $98(8)$ & $2.04(0.02)$ & $2.18(0.02)$ & $5.2(13)$ & $7.8(12)$ & 2.6 & 1.8 & -11.48 \\
\hline Procymidone & PCM & 3.3 & $9.6(41)$ & $69(19)$ & - & - & - & - & & & - \\
\hline Simazine & SMZ & 2.3 & $1.5(21)$ & $97(8)$ & $2.09(0.03)$ & $2.16(0.02)$ & $4.1(14)$ & $5.7(11)$ & 3.2 & 2.3 & -11.58 \\
\hline Spiroxamine & SPX & $5.5^{*}$ & $0.5(27)$ & $88(9)$ & - & $4.30(0.03)$ & $133(11)$ & 717 (14) & 13.9 & 2.6 & -11.15 \\
\hline Tebuconazole & TBZ & 3.7 & $23.9(15)$ & $87(6)$ & $2.95(0.03)$ & $2.77(0.01)$ & $35(12)$ & $44(10)$ & 1.5 & 1.2 & -11.19 \\
\hline
\end{tabular}

$671{ }^{a}$ University of Hertfordshire. Pesticide Properties DataBase: http://sitem.herts.ac.uk/aeru/ppdb/en/atoz.htm

672 * Predicted by ChemAxon: http://www.chemicalize.org/structure 
Calibration of silicone rubber rods as passive samplers for pesticides at two different flow velocities: Modelling of sampling rates under water boundary layer and polymer control

A. Martin $\uparrow$, C. Margoum* $\uparrow$, A. Jolivet $\uparrow$, A. Assoumani $\uparrow$, B. El Moujahid $\uparrow$, J. Randon $\ddagger$, M. Coquery $\dagger$

† Irstea, UR MALY, 5 rue de la Doua, BP 32108, F-69616 Villeurbanne Cedex, France

† Univ Lyon, CNRS, Université Claude Bernard Lyon 1, ENS de Lyon, Institut des Sciences Analytiques, UMR 5280, 5 rue de la Doua, F-69100 Villeurbanne, France

*Corresponding author: Tel: + 334722087 11; Fax: + 3347847 78 75; Email address: christelle.margoum@irstea.fr

\section{Supplementary Information}


SI-1. Pesticide parameters for UHPLC-MS/MS analysis.

\begin{tabular}{|c|c|c|c|c|c|}
\hline Compound & $\underset{\left(\mu g L^{-1}\right)}{\mathbf{L O Q}}$ & $\begin{array}{l}\text { Quantification } \\
\text { transitions }(m / z)\end{array}$ & $\begin{array}{l}\text { Declustering } \\
\text { potential (V) }\end{array}$ & $\begin{array}{c}\text { Collision energy } \\
\text { (V) }\end{array}$ & $\begin{array}{l}\text { Collision exit } \\
\text { potential (V) }\end{array}$ \\
\hline ATC & 0.40 & $\begin{array}{c}269.9>224.2 ; \\
269.9>148.1\end{array}$ & $\begin{array}{l}31 \\
31\end{array}$ & $\begin{array}{l}15 \\
27\end{array}$ & $\begin{array}{l}16 \\
14\end{array}$ \\
\hline ATZ & 0.10 & $\begin{array}{c}215.9>174.1 \\
215.9>104.1\end{array}$ & $\begin{array}{l}66 \\
66\end{array}$ & $\begin{array}{l}25 \\
41\end{array}$ & $\begin{array}{c}16 \\
8\end{array}$ \\
\hline AZS & 0.02 & $\begin{array}{c}404>372 \\
404>344\end{array}$ & $\begin{array}{l}61 \\
61\end{array}$ & $\begin{array}{l}33 \\
35\end{array}$ & $\begin{array}{l}26 \\
28\end{array}$ \\
\hline BOS & 0.20 & $\begin{array}{c}343>307 \\
343>140\end{array}$ & $\begin{array}{l}81 \\
81\end{array}$ & $\begin{array}{l}25 \\
29\end{array}$ & $\begin{array}{c}28 \\
8\end{array}$ \\
\hline CBZ & 0.02 & $\begin{array}{c}192>160 ; \\
192>132\end{array}$ & $\begin{array}{l}56 \\
56\end{array}$ & $\begin{array}{l}25 \\
41\end{array}$ & $\begin{array}{l}16 \\
24\end{array}$ \\
\hline CFV & 0.16 & $\begin{array}{c}359>155 \\
359>99\end{array}$ & $\begin{array}{l}76 \\
76\end{array}$ & $\begin{array}{l}17 \\
43\end{array}$ & $\begin{array}{c}20 \\
8\end{array}$ \\
\hline CPE & 0.40 & $\begin{array}{c}352>200 \\
350>97\end{array}$ & $\begin{array}{l}45 \\
61\end{array}$ & $\begin{array}{l}30 \\
55\end{array}$ & $\begin{array}{c}38 \\
4\end{array}$ \\
\hline CPM & 0.40 & $\begin{array}{l}322>125 ; \\
322>290\end{array}$ & $\begin{array}{l}71 \\
71\end{array}$ & $\begin{array}{l}29 \\
23\end{array}$ & $\begin{array}{l}22 \\
54\end{array}$ \\
\hline CTU & 0.40 & $\begin{array}{l}213>72 ; \\
213>140\end{array}$ & $\begin{array}{l}51 \\
51\end{array}$ & $\begin{array}{l}25 \\
37\end{array}$ & $\begin{array}{c}12 \\
6\end{array}$ \\
\hline DCA & 0.40 & $\begin{array}{c}162>127 ; \\
162>74\end{array}$ & $\begin{array}{l}51 \\
51\end{array}$ & $\begin{array}{l}31 \\
73\end{array}$ & $\begin{array}{l}24 \\
14\end{array}$ \\
\hline DCPMU & 0.16 & $\begin{array}{c}219>162 ; \\
219>127\end{array}$ & $\begin{array}{l}66 \\
66\end{array}$ & $\begin{array}{l}21 \\
37\end{array}$ & $\begin{array}{l}26 \\
22\end{array}$ \\
\hline DFF & 0.40 & $\begin{array}{c}395>266 ; \\
395>246\end{array}$ & $\begin{array}{l}86 \\
86\end{array}$ & $\begin{array}{l}35 \\
47\end{array}$ & $\begin{array}{l}28 \\
40\end{array}$ \\
\hline DIU & 0.40 & $\begin{array}{c}233>72 \\
233>46\end{array}$ & $\begin{array}{l}46 \\
46\end{array}$ & $\begin{array}{l}51 \\
37\end{array}$ & $\begin{array}{l}6 \\
8\end{array}$ \\
\hline DMM & 0.16 & $\begin{array}{c}388>301 \\
388>165\end{array}$ & $\begin{array}{l}76 \\
76\end{array}$ & $\begin{array}{l}31 \\
43\end{array}$ & $\begin{array}{l}36 \\
28\end{array}$ \\
\hline FNT & 4.00 & $\begin{array}{c}278>125 \\
278>109\end{array}$ & $\begin{array}{l}71 \\
71\end{array}$ & $\begin{array}{l}29 \\
25\end{array}$ & $\begin{array}{l}22 \\
16\end{array}$ \\
\hline IMD & 0.10 & $\begin{array}{c}256>209.1 \\
256>175.1\end{array}$ & $\begin{array}{l}61 \\
61\end{array}$ & $\begin{array}{l}23 \\
27\end{array}$ & $\begin{array}{l}38 \\
12\end{array}$ \\
\hline IPU & 0.16 & $\begin{array}{l}207>72 \\
207>165\end{array}$ & $\begin{array}{l}51 \\
51\end{array}$ & $\begin{array}{l}37 \\
19\end{array}$ & $\begin{array}{c}8 \\
28\end{array}$ \\
\hline LINU & 0.16 & $\begin{array}{c}249>160 \\
249>182\end{array}$ & $\begin{array}{l}61 \\
61\end{array}$ & $\begin{array}{l}25 \\
19\end{array}$ & $\begin{array}{l}32 \\
12\end{array}$ \\
\hline MTC & 0.04 & $\begin{array}{c}284.1>252.2 \\
284.1>176.2\end{array}$ & $\begin{array}{l}46 \\
46\end{array}$ & $\begin{array}{l}21 \\
37\end{array}$ & $\begin{array}{c}20 \\
4\end{array}$ \\
\hline NFZ & 0.40 & $\begin{array}{c}304>284 \\
304>88\end{array}$ & $\begin{array}{l}101 \\
101\end{array}$ & $\begin{array}{l}35 \\
61\end{array}$ & $\begin{array}{l}26 \\
16\end{array}$ \\
\hline PCM & 1.60 & $284>256$ & 76 & 25 & 46 \\
\hline SMZ & 0.02 & $\begin{array}{c}202.1>132.2 ; \\
202.1>124.1\end{array}$ & $\begin{array}{l}56 \\
56\end{array}$ & $\begin{array}{l}29 \\
27\end{array}$ & $\begin{array}{l}10 \\
10\end{array}$ \\
\hline SPX & 0.16 & $\begin{array}{c}298>144 \\
298>100\end{array}$ & $\begin{array}{l}51 \\
51\end{array}$ & $\begin{array}{l}31 \\
45\end{array}$ & $\begin{array}{c}8 \\
18\end{array}$ \\
\hline TBZ & 0.16 & $\begin{array}{l}308>70 \\
308>125\end{array}$ & $\begin{array}{l}76 \\
76\end{array}$ & $\begin{array}{l}51 \\
57\end{array}$ & $\begin{array}{l}12 \\
12\end{array}$ \\
\hline
\end{tabular}




\begin{tabular}{|c|c|c|c|c|c|}
\hline Compound & $\begin{array}{c}\mathrm{LOQ} \\
\left(\mu \mathrm{g} \mathrm{L}^{-1}\right)\end{array}$ & $\begin{array}{l}\text { Quantification } \\
\text { transitions }(\mathrm{m} / \mathrm{z})\end{array}$ & $\begin{array}{l}\text { Declustering } \\
\text { potential (V) }\end{array}$ & $\begin{array}{l}\text { Collision energy } \\
\text { (V) }\end{array}$ & $\begin{array}{l}\text { Collision exit } \\
\text { potential (V) }\end{array}$ \\
\hline ATC-d11 & 0.40 & $\begin{array}{c}281.1>235.1 \\
281.1>159.1\end{array}$ & $\begin{array}{l}31 \\
31\end{array}$ & $\begin{array}{l}13 \\
29\end{array}$ & $\begin{array}{l}20 \\
12\end{array}$ \\
\hline ATZ-d5 & 0.10 & $\begin{array}{c}221.06>179.1 ; \\
221.06>101.1\end{array}$ & $\begin{array}{l}46 \\
46\end{array}$ & $\begin{array}{l}27 \\
35\end{array}$ & $\begin{array}{l}18 \\
18\end{array}$ \\
\hline CBZ-d4 & 0.02 & $\begin{array}{c}196>164.1 \\
196>138.1\end{array}$ & $\begin{array}{l}61 \\
61\end{array}$ & $\begin{array}{l}29 \\
41\end{array}$ & $\begin{array}{c}12 \\
8\end{array}$ \\
\hline CFV-d10 & 0.16 & $\begin{array}{c}369.1>165.2 \\
369.1>101.2\end{array}$ & $\begin{array}{l}56 \\
56\end{array}$ & $\begin{array}{l}19 \\
45\end{array}$ & $\begin{array}{l}10 \\
10\end{array}$ \\
\hline CPE-d10 & 0.40 & $\begin{array}{c}360>199 \\
360>163\end{array}$ & $\begin{array}{l}66 \\
66\end{array}$ & $\begin{array}{l}29 \\
21\end{array}$ & $\begin{array}{l}14 \\
14\end{array}$ \\
\hline CPM-d6 & 0.40 & $\begin{array}{c}328>131.2 \\
328>292.9\end{array}$ & $\begin{array}{l}66 \\
66\end{array}$ & $\begin{array}{l}31 \\
23\end{array}$ & $\begin{array}{c}8 \\
22\end{array}$ \\
\hline DFF-d3 & 0.40 & $\begin{array}{c}398>268 \\
398>248\end{array}$ & $\begin{array}{l}76 \\
76\end{array}$ & $\begin{array}{l}31 \\
49\end{array}$ & $\begin{array}{l}16 \\
20\end{array}$ \\
\hline DIU d6 & 0.40 & $\begin{array}{c}239>78 \\
239>52\end{array}$ & $\begin{array}{l}66 \\
66\end{array}$ & $\begin{array}{l}43 \\
37\end{array}$ & $\begin{array}{l}14 \\
10\end{array}$ \\
\hline FNT-d6 & 4.00 & $\begin{array}{c}284>131 \\
284>249\end{array}$ & $\begin{array}{l}61 \\
61\end{array}$ & $\begin{array}{l}27 \\
25\end{array}$ & $\begin{array}{l}18 \\
12\end{array}$ \\
\hline IPU-d6 & 0.16 & $\begin{array}{l}213.1>78.3 ; \\
213.1>171.2\end{array}$ & $\begin{array}{l}66 \\
66\end{array}$ & $\begin{array}{l}27 \\
21\end{array}$ & $\begin{array}{l}24 \\
10\end{array}$ \\
\hline LINU-d6 & 0.16 & $\begin{array}{c}255>159.9 \\
255>185\end{array}$ & $\begin{array}{l}56 \\
56\end{array}$ & $\begin{array}{l}25 \\
21\end{array}$ & $\begin{array}{c}8 \\
14\end{array}$ \\
\hline MTC-d6 & 0.04 & $\begin{array}{c}290.1>258.1 ; \\
290.1>182.2\end{array}$ & $\begin{array}{l}65 \\
65\end{array}$ & $\begin{array}{l}21 \\
35\end{array}$ & $\begin{array}{l}22 \\
32\end{array}$ \\
\hline SMZ-d5 & 0.02 & $\begin{array}{c}207>129.1 \\
207>137.1\end{array}$ & $\begin{array}{l}71 \\
71\end{array}$ & $\begin{array}{l}29 \\
27\end{array}$ & $\begin{array}{l}6 \\
8\end{array}$ \\
\hline TBZ-d6 & 0.16 & $\begin{array}{l}314>72 ; \\
314>125 \\
\end{array}$ & $\begin{array}{l}81 \\
81\end{array}$ & $\begin{array}{l}77 \\
53\end{array}$ & $\begin{array}{l}12 \\
10\end{array}$ \\
\hline
\end{tabular}


SI-2. Schematic diagrams (top and side view) of the laboratory static calibration system with dimensions in $\mathbf{m m}$.

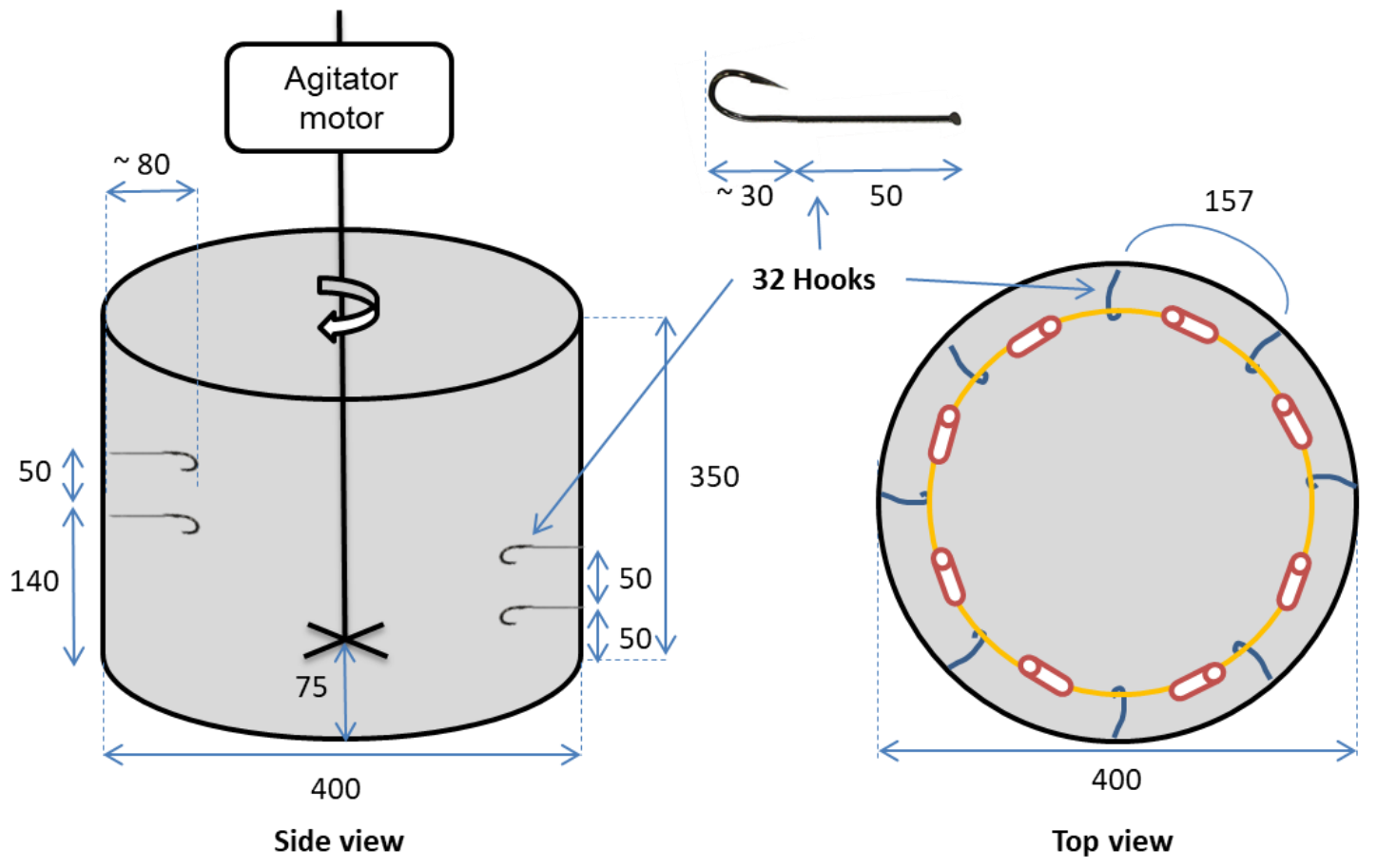


SI-3. Uptake of pesticides and release of corresponding deuterated pesticide (candidate PRCs) by the silicone rods (SRs) at two flow velocities (5 and $20 \mathrm{~cm} \cdot \mathrm{s}^{-1}$ ).

Accumulated mass $(m)$ is plotted relative to the initial mass for the release $\left(m_{0}\right)$ and to the predicted equilibrium mass for the uptake $\left(m_{e q}\right)$.
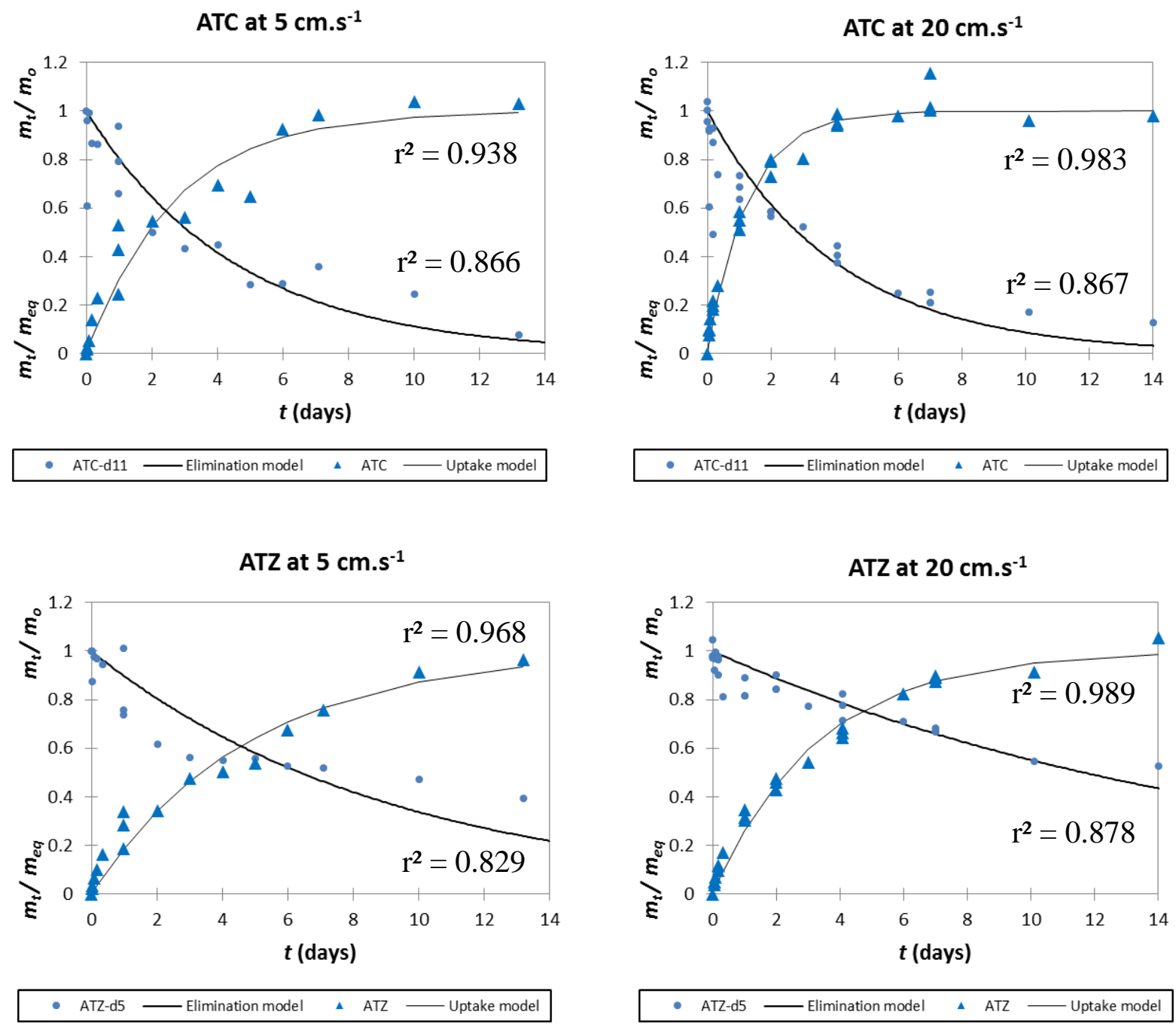


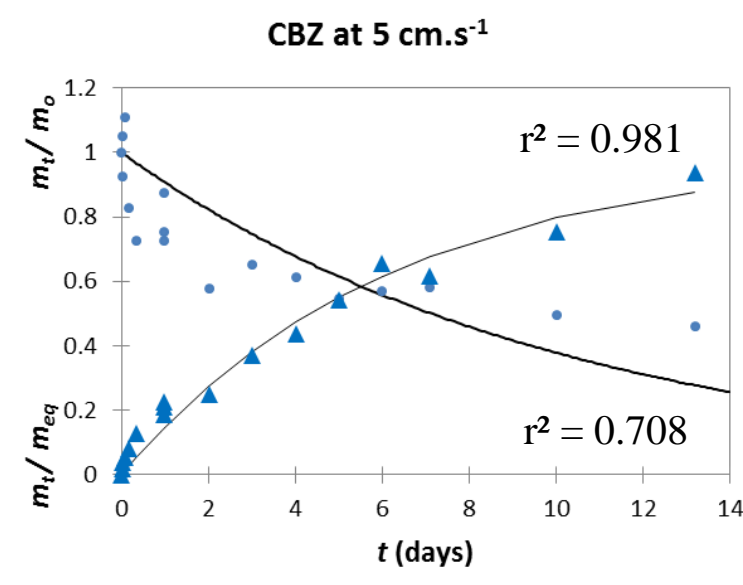

- CBZ-d4 Elimination model $\triangle \mathrm{CBZ} \longrightarrow$ Uptake model

CFV at $5 \mathrm{~cm} \cdot \mathrm{s}^{-1}$

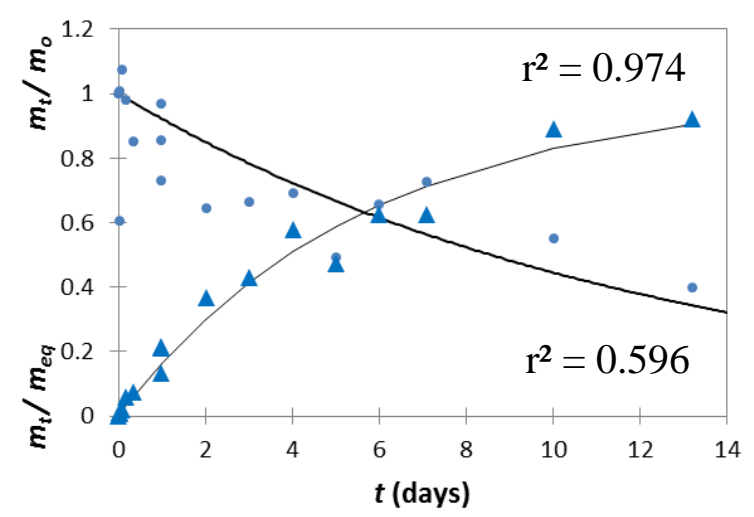

- CFV-d10 Elimination model $\triangle$ CFV $\longrightarrow$ Uptake model

CPE at $5 \mathrm{~cm} \cdot \mathrm{s}^{-1}$

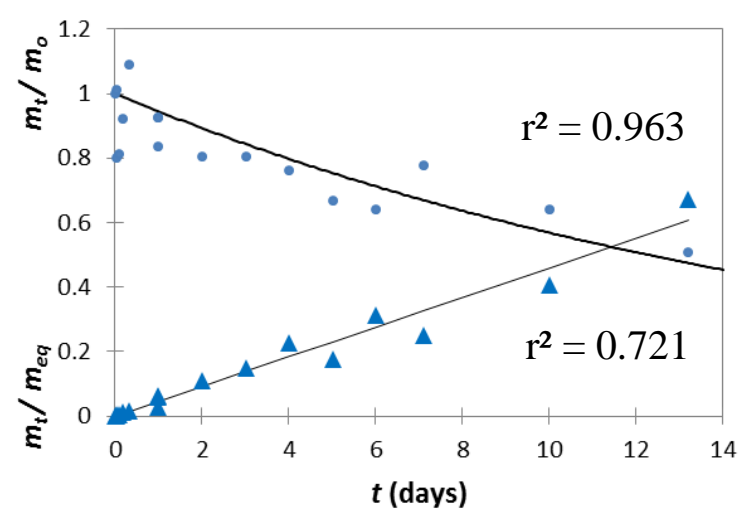

- CPE-d10 Elimination model $\triangle$ CPE —uptake model
$\mathrm{CBZ}$ at $20 \mathrm{~cm} \cdot \mathrm{s}^{-1}$

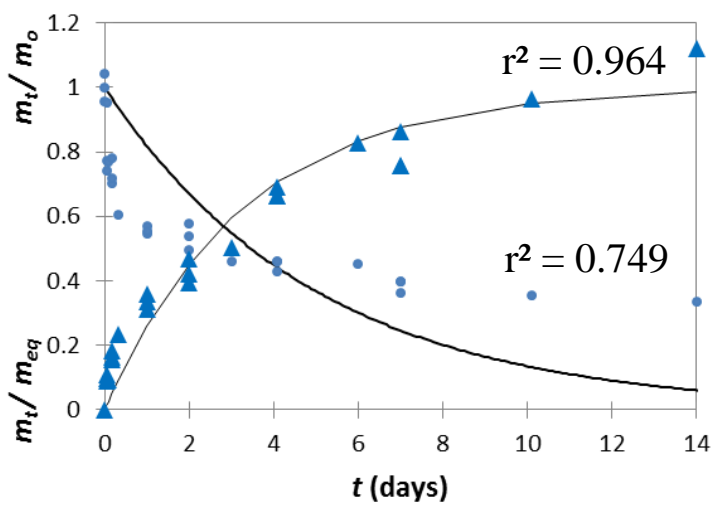

- CBZ-d4 Elimination model $\triangle$ CBZ $\longrightarrow$ Uptake model

CFV at $20 \mathrm{~cm} \cdot \mathrm{s}^{-1}$

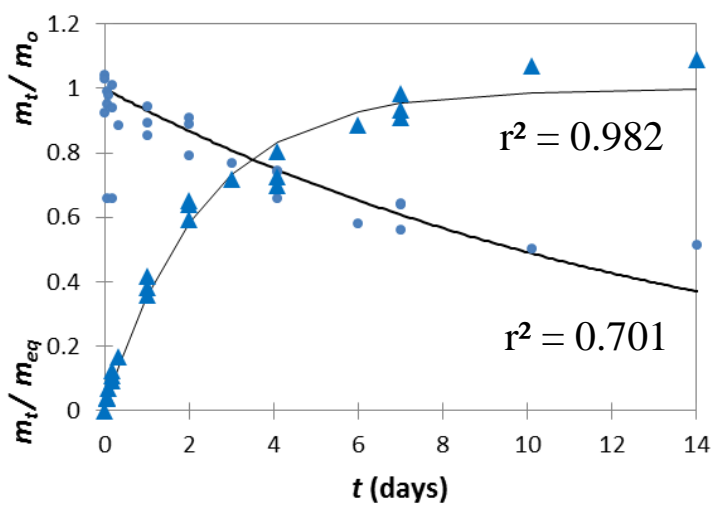

- CFV-d10 Elimination model $\triangle$ CFV Uptake model

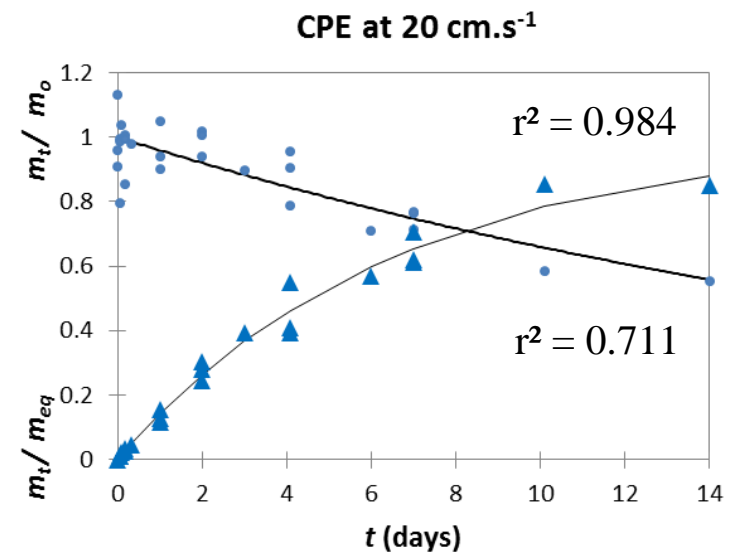

- CPE-d10 Elimination model $\triangle$ CPE — Uptake model 


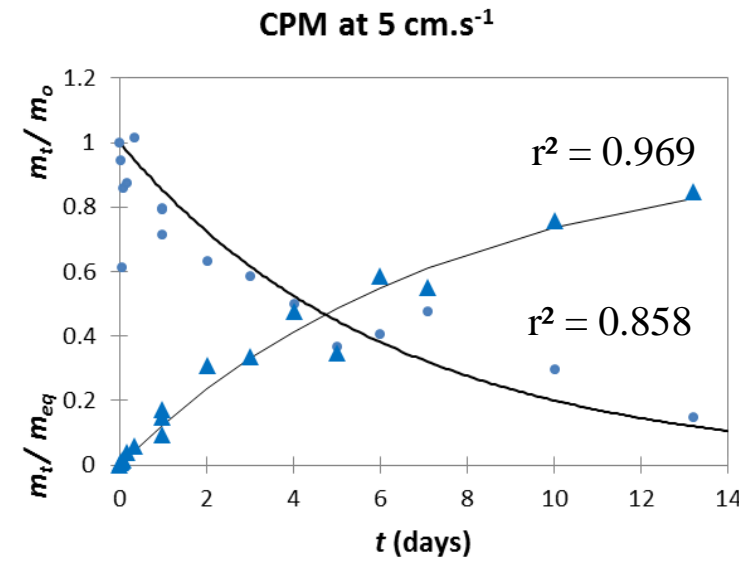

- CPMD-d6 - Elimination model $\triangle$ CPM - Uptake model

DFF at $5 \mathrm{~cm} \cdot \mathrm{s}^{-1}$

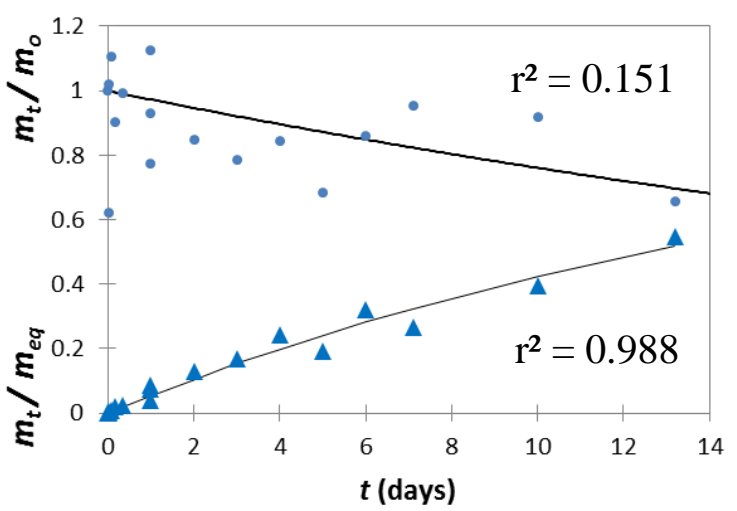

- DFF-d3 - Elimination model $\triangle$ DFF $\longleftarrow$ Uptake model

FNT at $5 \mathrm{~cm} . \mathrm{s}^{-1}$

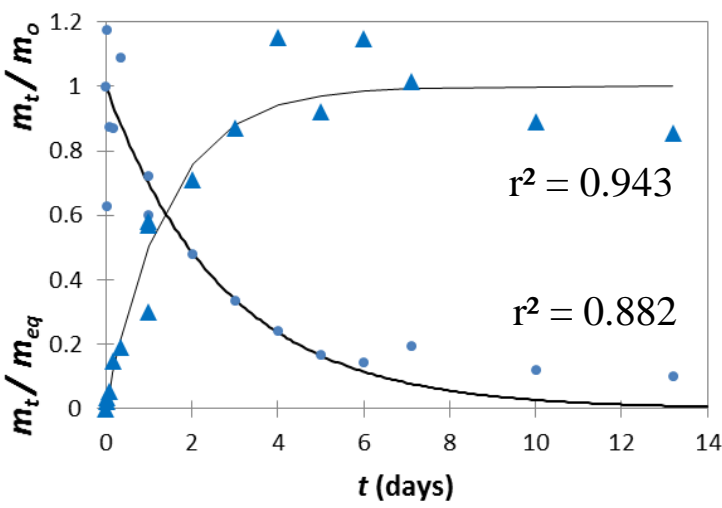

- FNT-d6 Elimination model $\triangle$ FNT $\longrightarrow$ Uptake model
CPM at $20 \mathrm{~cm} \cdot \mathrm{s}^{-1}$

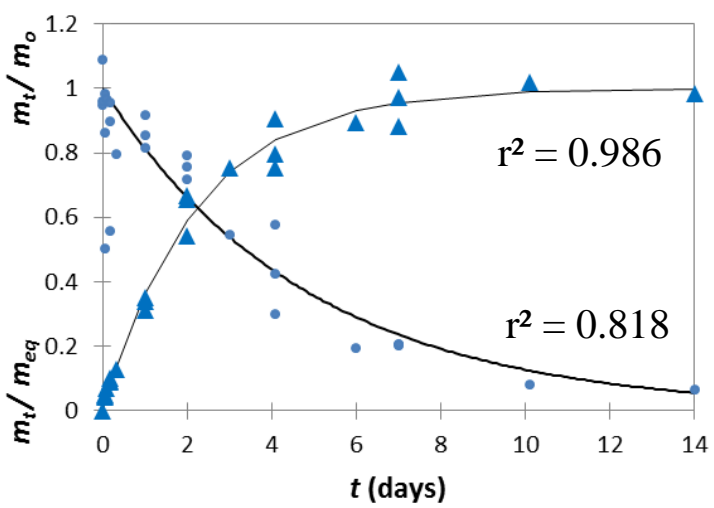

- CPM-d6 Elimination model $\triangle$ CPM Uptake model

DFF at $20 \mathrm{~cm} . \mathrm{s}^{-1}$

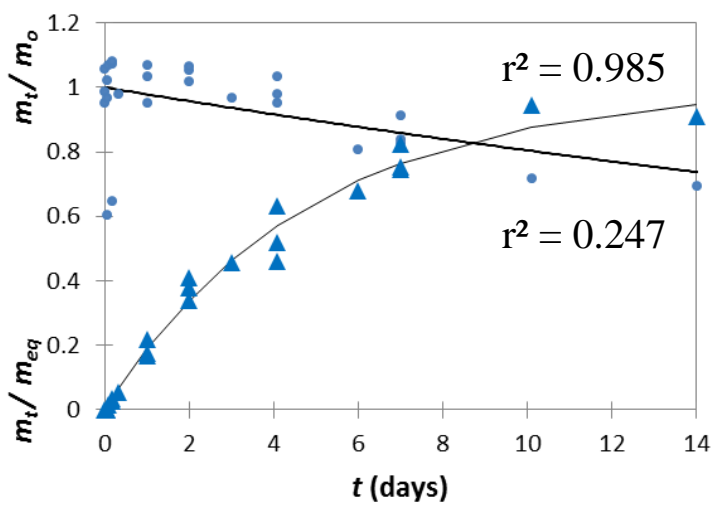

DFF-d3 Elimination model $\triangle$ DFF $\longrightarrow$ Uptake model

FNT at $20 \mathrm{~cm} \cdot \mathrm{s}^{-1}$

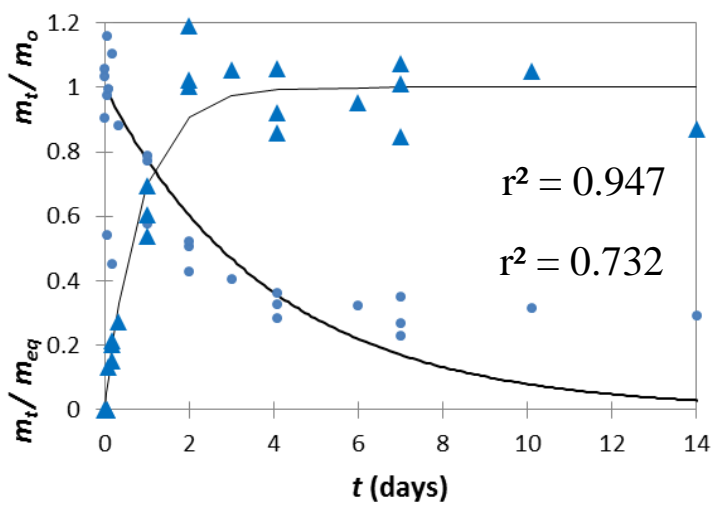

- FNT-d6 Elimination model $\triangle$ FNT $\longrightarrow$ Uptake model 
IPU at $5 \mathrm{~cm} \cdot \mathrm{s}^{-1}$

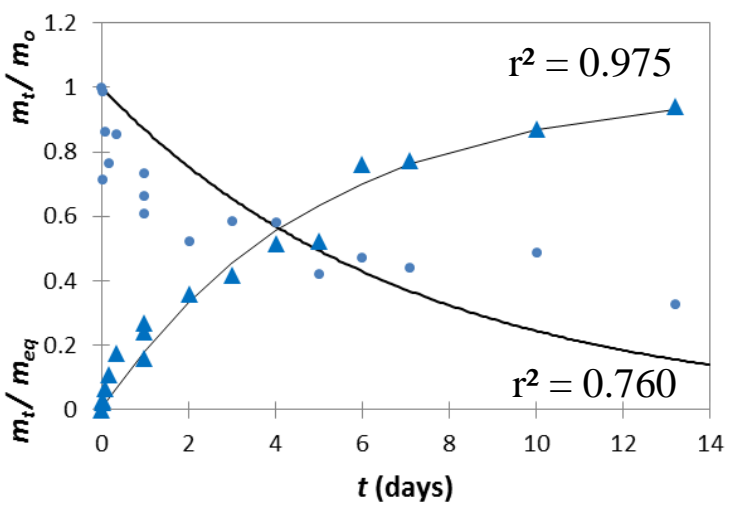

- IPU-d6 - Elimination model $\triangle$ IPU $\longrightarrow$ Uptake model

LINU at $5 \mathrm{~cm} \cdot \mathrm{s}^{-1}$

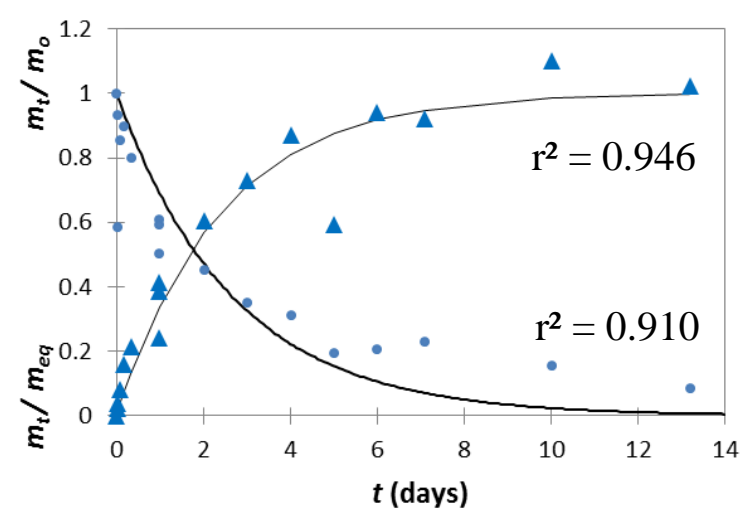

- LINU-d6 - Elimination model $\triangle$ LINU —Uptake model

MTC at $5 \mathrm{~cm} . \mathrm{s}^{-1}$

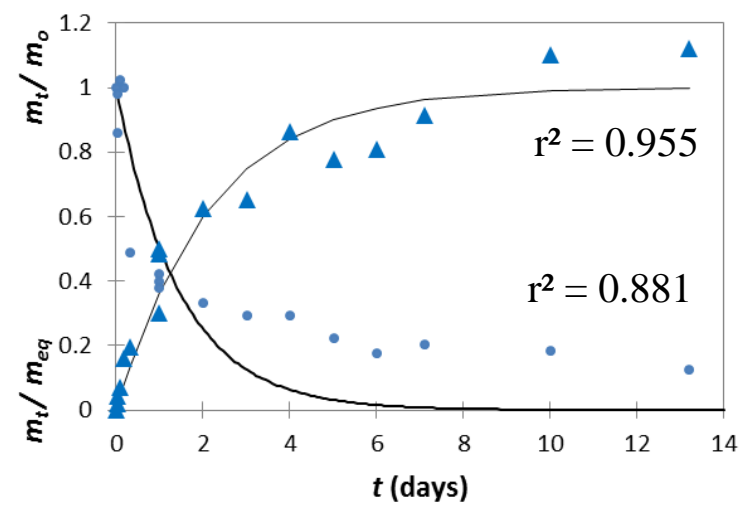

- MTC-d6 Elimination model A MTC — Uptake model
IPU at $20 \mathrm{~cm} \cdot \mathrm{s}^{-1}$

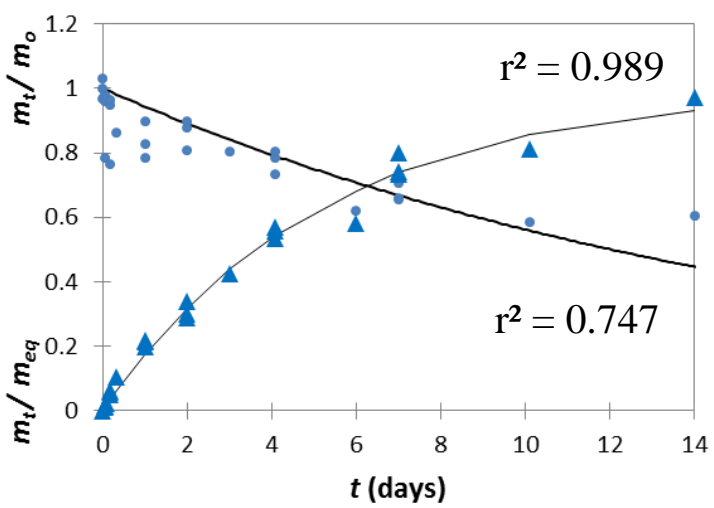

- IPU-d6 - Elimination model $\triangle$ IPU —u Uptake model

LINU at $20 \mathrm{~cm} . \mathrm{s}^{-1}$

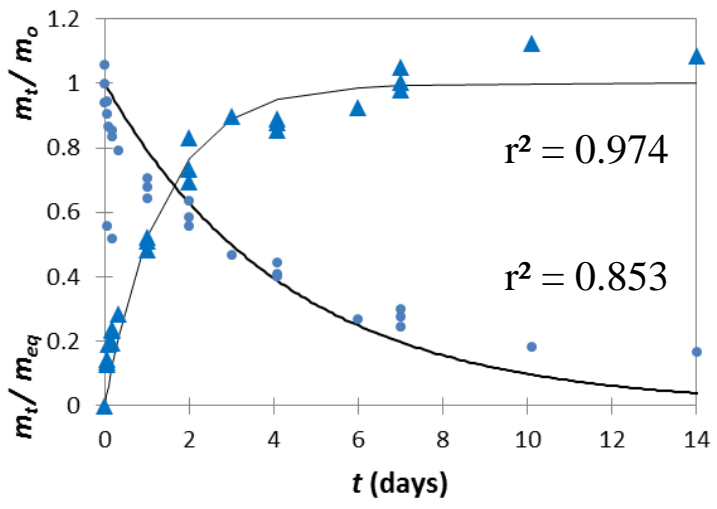

- LINU-d6 Elimination model \ LINU —Uptake model

MTC at $20 \mathrm{~cm} . \mathrm{s}^{-1}$

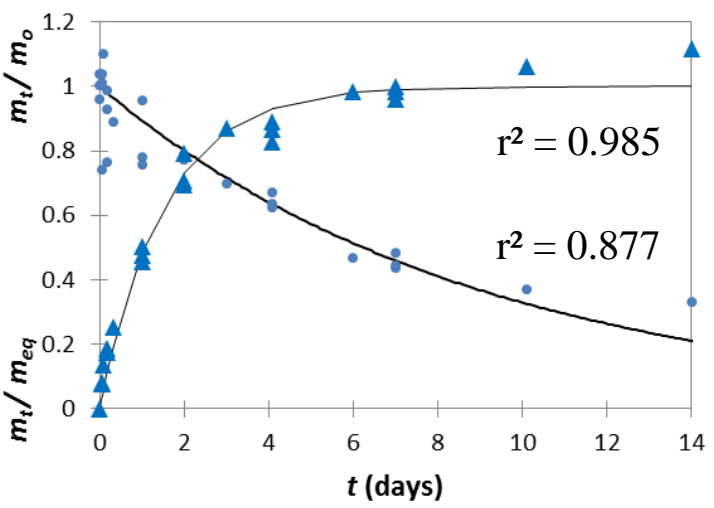

- MTC-d6 Elimination model \ MTC —U Uptake model 


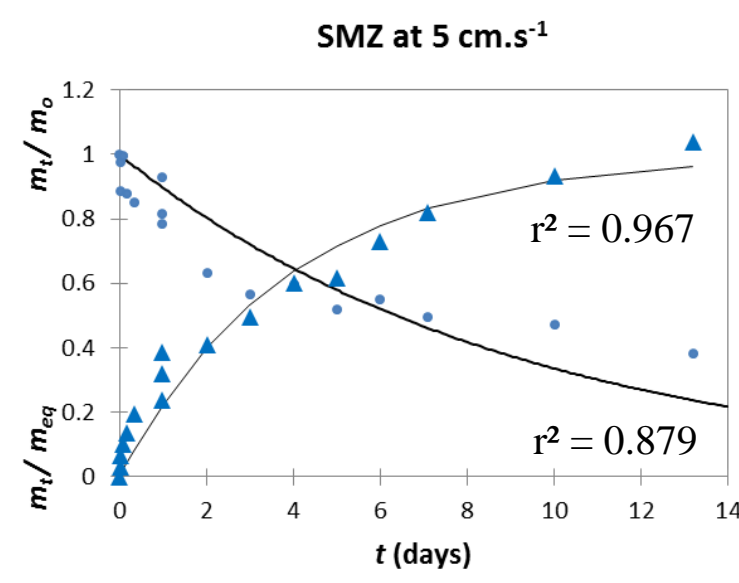

- SMZ-d5 —Elimination model $\triangle$ SMZ —u Uptake model

TBZ at $5 \mathrm{~cm} . \mathrm{s}^{-1}$

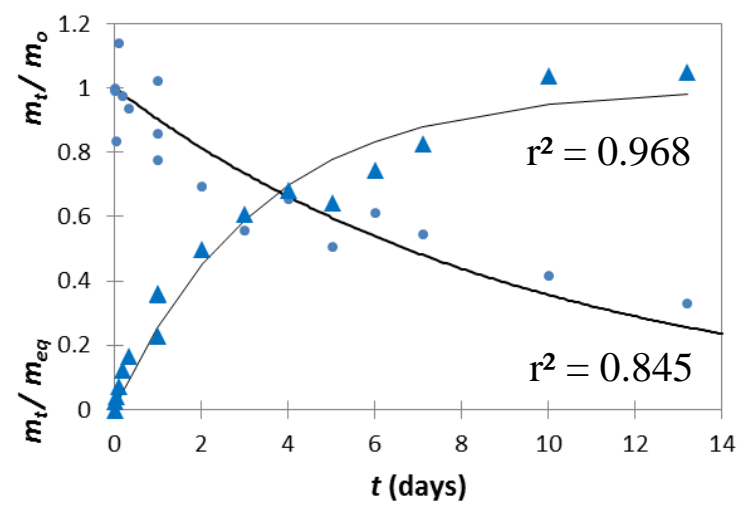

- TBZ-d6 Elimination model $\triangle$ TBZ — Uptake model
$\mathrm{SMZ}$ at $20 \mathrm{~cm} \cdot \mathrm{s}^{-1}$

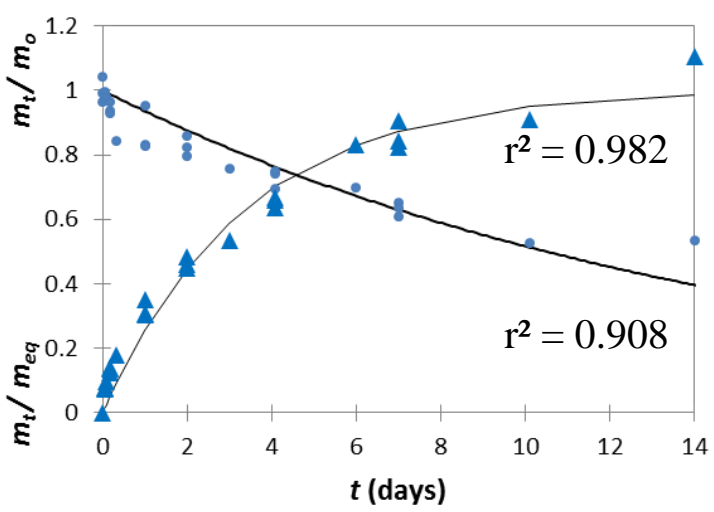

- SMZ-d5 - Elimination model $\triangle$ SMZ U Uptake model

TBZ at $20 \mathrm{~cm} . \mathrm{s}^{-1}$

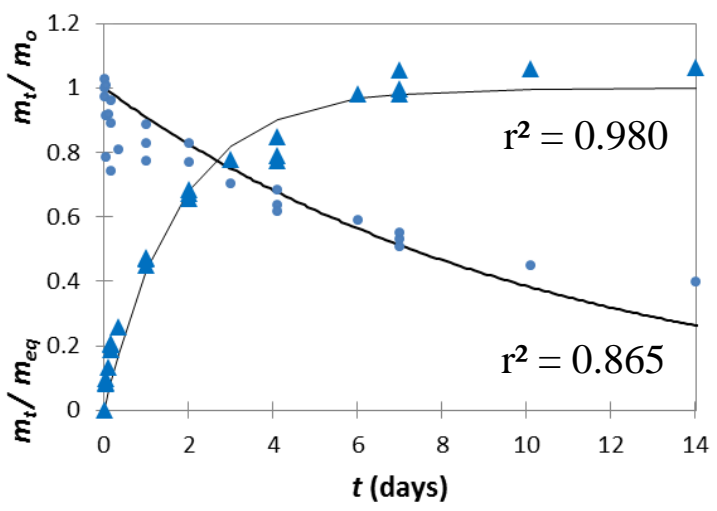

- TBZ-d6 Elimination model $\triangle$ TBZ $\longleftarrow$ Uptake model 
SI-4. Plot of $K_{s w}$ values from the experiments at two flow velocities (Eq.7) and estimated by the Freundlich model $\left(K_{s w}=K_{f} C_{w e q}{ }^{1 / n-1}\right.$ with parameters from Martin et al. [1]) at the concentration of this experiment against $K_{s w}$ estimated in Martin et al. [1].

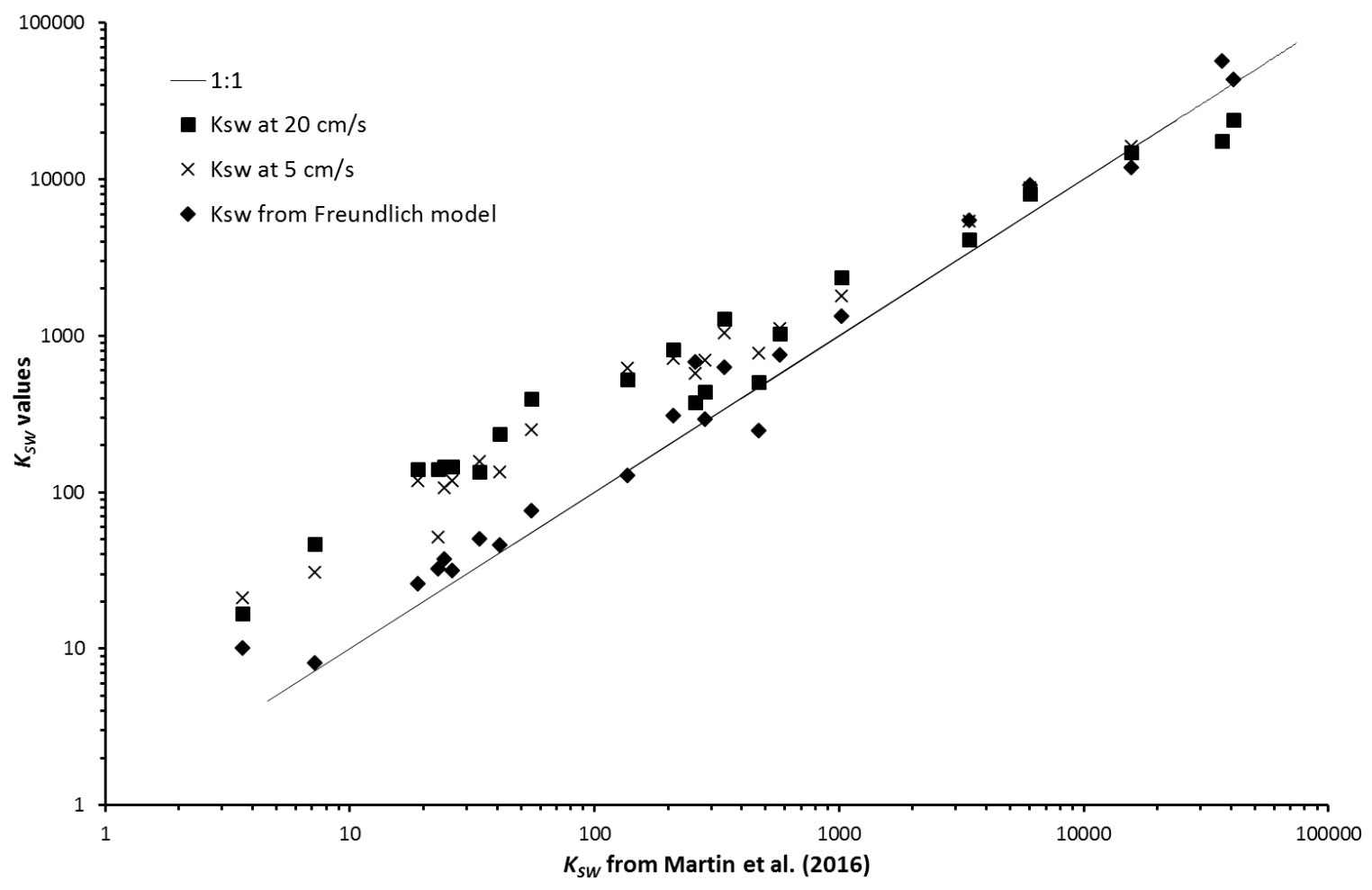


SI-5. Molecular properties $\left(M, V_{m}, \log D_{w}\right)$ of pesticides.

\begin{tabular}{|c|c|c|c|}
\hline Pesticide & $\begin{array}{c}M^{\mathrm{a}} \\
\left(\mathrm{g} \mathrm{mol}^{-1}\right) \\
\end{array}$ & $\begin{array}{c}V_{m}^{\mathrm{a}} \\
\left(\mathrm{cm}^{3} \mathrm{~mol}^{-1}\right) \\
\end{array}$ & $\begin{array}{c}\log D_{w}{ }^{b} \\
\left(\mathrm{~m}^{2} \mathbf{s}^{-1}\right) \\
\end{array}$ \\
\hline ATC & 269.8 & 240.9 & -9.28 \\
\hline ATZ & 215.7 & 163.1 & -9.18 \\
\hline AZS & 403.4 & 300.1 & -9.34 \\
\hline BOS & 342.2 & 262.1 & -9.3 \\
\hline CBZ & 191.2 & 137.5 & -9.14 \\
\hline CFV & 359.6 & 261.8 & -9.30 \\
\hline CPE & 350.6 & 236.8 & -9.28 \\
\hline CPM & 322.5 & 203.8 & -9.24 \\
\hline CTU & 212.7 & 184.5 & -9.21 \\
\hline DCA & 162.0 & 115.6 & -9.09 \\
\hline DCPMU & 219.1 & 152.1 & -9.16 \\
\hline DFF & 394.3 & 274.0 & -9.31 \\
\hline DIU & 233.1 & 178.6 & -9.21 \\
\hline DMM & 387.9 & 315.1 & -9.35 \\
\hline FNT & 277.2 & 202.8 & -9.24 \\
\hline IMD & 255.7 & 160.1 & -9.18 \\
\hline IPU & 206.3 & 196.3 & -9.23 \\
\hline LINU & 249.1 & 185.2 & -9.21 \\
\hline MTC & 283.8 & 257.8 & -9.30 \\
\hline NFZ & 303.7 & 208.8 & -9.24 \\
\hline РCM & 284.1 & 189.1 & -9.22 \\
\hline SMZ & 201.7 & 147.9 & -9.16 \\
\hline SPX & 297.5 & 308.2 & -9.34 \\
\hline TBZ & 307.8 & 268.1 & -9.31 \\
\hline
\end{tabular}

${ }^{a}$ Predicted by ACD/Labs: http://www.chemspider.coml

${ }^{b}$ Calculated from Hayduk and Laudie (1974) 
1 SI-6. Plot of $\log D s$ versus molar mass $(M)$ and molar volume $\left(V_{m}\right)$ for PAHs and PCBs

2 (experimental values from Rusina et al. [2]) and for pesticides (estimated from this study).
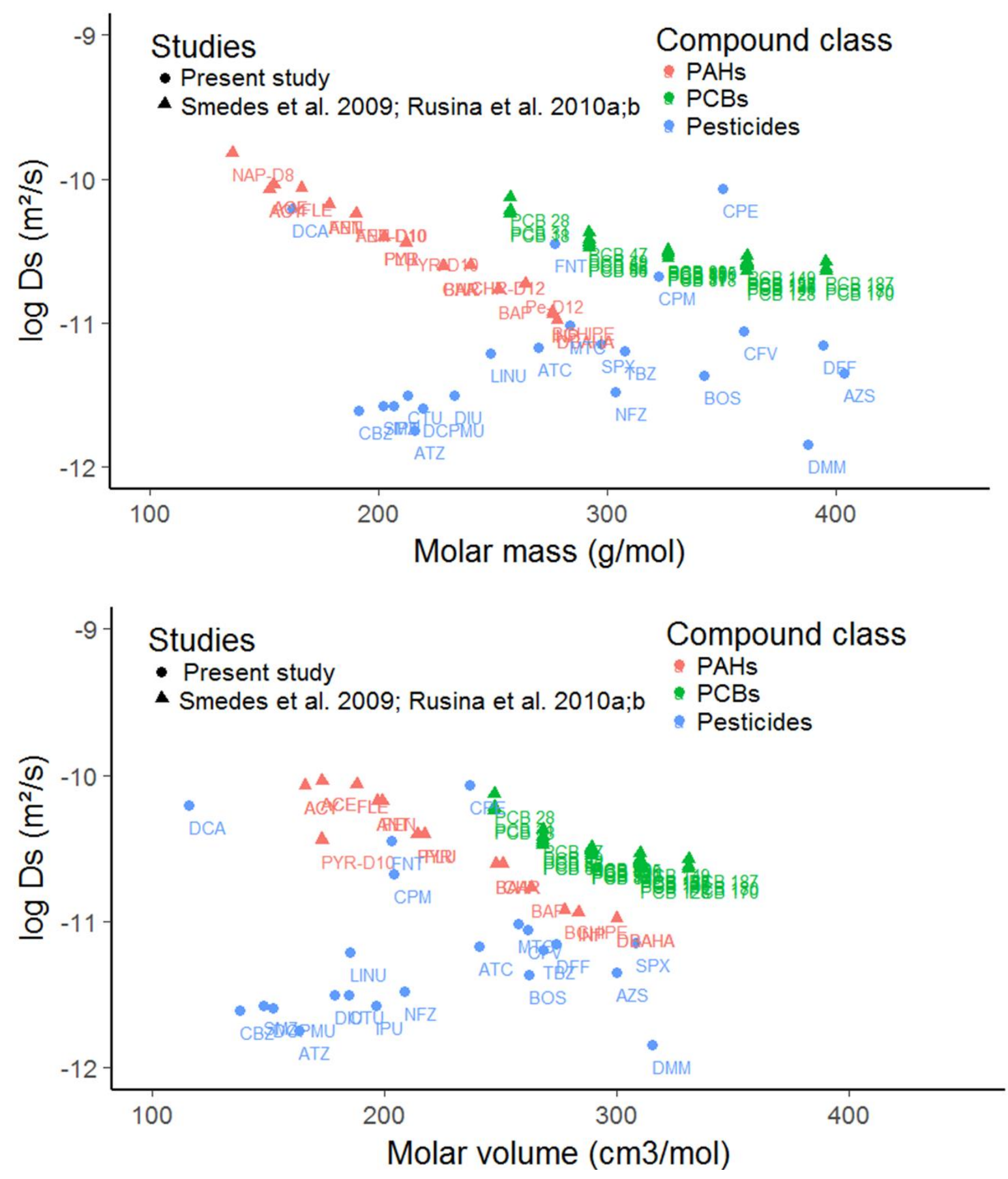
SI-7. Spreadsheet file compiling results from the two calibration experiments for 24 pesticides and 13 candidate PRCs at two flow velocities (5 and $\left.20 \mathrm{~cm} \cdot \mathrm{s}^{-1}\right)$. Accumulated

6 mass of pesticides ( $m$, ng) were not corrected by corresponding solvent back extraction

7 recoveries (Table 1). Concentrations of pesticides in water $\left(C_{w}\right)$ was expressed in $\mu \mathrm{g} \mathrm{L}^{-1}$.

\section{References}

11 [1] Martin A, Margoum C, Randon J, Coquery M. 2016. Silicone rubber selection for passive 12 sampling of pesticides in water. Talanta 160:306-313.

13 [2] Rusina TP, Smedes F, Klanova J. 2010. Diffusion Coefficients of Polychlorinated

14 Biphenyls and Polycyclic Aromatic Hydrocarbons in Polydimethylsiloxane and Low-Density

15 Polylethylene Polymers. Journal of Applied Polymer Science 116:1803-1810.

16 [3] Rusina TP, Smedes F, Koblizkova M, Klanova J. 2010. Calibration of silicone rubber

17 passive samplers: experimental and modeled relations between sampling rate and compound

18 properties. Environmental Science \& Technology 44:362-367.

19

20 